\title{
Susceptibility to Anti-Glomerular Basement Membrane Disease and Goodpasture Syndrome Is Linked to MHC Class II Genes and the Emergence of T Cell-mediated Immunity in Mice
}

\author{
Raghuram Kalluri, Theodore M. Danoff, Hirokazu Okada, and Eric G. Neilson \\ Penn Center for Molecular Studies of Kidney Diseases, University of Pennsylvania, Philadelphia, Pennsylvania 19104
}

\begin{abstract}
We developed a new mouse model of human anti-glomerular basement membrane (GBM) disease to better characterize the genetic determinants of cell-mediated injury. While all major histocompatibility complex (MHC) haplotypes (H-2 $2^{a}, \mathrm{k}, \mathrm{s}, \mathrm{b}$, and $\left.\mathrm{d}\right)$ immunized with $\alpha 3 \mathrm{NC1}$ domains of type IV collagen produce anti- $\alpha 3$ (IV) NC1 antibodies that crossreact with human Goodpasture [anti-GBM/anti- $\alpha 3$ (IV) NC1] autoantibodies, only a few strains developed nephritis and lung hemorrhage associated with Goodpasture syndrome. Crescentic glomerulonephritis and lung hemorrhage were MHC-restricted in haplotypes $\mathrm{H}-2^{\mathrm{s}}$, b, and d $(\mathrm{A} \beta / \mathrm{A} \alpha$ region in $\mathrm{H}^{-} \mathrm{2}^{\mathrm{s}}$ ) and associated with the emergence of an IL-12/ Th1-like $T$ cell phenotype. Lymphocytes or anti- $\alpha 3$ (IV) NC1 antibodies from nephritogenic strains transfer disease to syngeneic recipients. However, passive transfer of isogenic $\alpha 3(\mathrm{IV}) \mathrm{NC1}$ antibodies into $-I-\mathrm{T}$ cell receptor-deficient mice failed to produce nephritis. Finally, nephritis and its associated IL-12/Th1-like $T$ cell response attenuate in disease-susceptible mice tolerized orally to $\alpha 3$ (IV) collagen before immunization. Our findings suggest collectively, as a hypothesis, that anti-GBM antibodies in mice only facilitate disease in MHC haplotypes capable of generating nephritogenic lymphocytes with special T cell repertoires. (J. Clin. Invest. 1997. 100:2263-2275.) Key words: Goodpasture syndrome - type IV collagen - anti-basement membrane disease • $\alpha 3($ IV) NC1 • major histocompatibility complex
\end{abstract}

\section{Introduction}

The gene for human $\alpha 3$ (IV) collagen is found in the q35-37 region of chromosome 2 (1), and its protein largely replaces $\alpha 1$ (IV) and $\alpha 2$ (IV) collagens in the specialized basement membranes of the kidney during organ development (2). Chain mutations in $\alpha 3$ (IV) collagen produce autosomal reces-

This work was presented initially in abstract form at the National Meeting of the American Society of Nephrology in November, 1995.

Address correspondence to Eric G. Neilson, M.D., C. Mahlon Kline Professor of Medicine, 700 Clinical Research Building, University of Pennsylvania, 415 Curie Boulevard, Philadelphia, PA 191046144. Phone: 215-662-7633; FAX: 215-898-0189; E-mail: neilson@ mail.med.upenn.edu

Received for publication 21 May 1997 and accepted in revised form 11 September 1997.

J. Clin. Invest.

(C) The American Society for Clinical Investigation, Inc. 0021-9738/97/11/2263/13 \$2.00

Volume 100, Number 9, November 1997, 2263-2275

http://www.jci.org sive Alport syndrome (3), and humans occasionally develop autoimmune responses to the $\alpha 3$ (IV) NC1 resulting in antiglomerular basement membrane (GBM) nephritis or Goodpasture syndrome $(\mathrm{GPS})^{1}(4,5)$. Evidence of genetic susceptibility to human anti-GBM disease is limited to studies in twins $(6,7)$, and to an association with MHC haplotypes mapping to the class II HLA-D region $(8,9)$. Anti-GBM antibodies and T cells from Goodpasture patients recognize epitopes found at the distal termini of the recombinant $\alpha 3 \mathrm{NC} 1$ domain of type IV collagen (10-13).

Human anti-GBM antibodies eluted from nephritic kidney are thought to be etiologic for disease because they passively transfer a heterologous nephritis to primates (14). However, the nature of the passive experiments precluded allotypematching of anti-GBM antibodies for recipients, and, therefore, was not a strong test for antibody sufficiency in an autologous environment. Likewise, it has not been feasible to adoptively transfer human lymphocytes reactive with $\alpha 3(\mathrm{IV})$ collagen to assess cell-mediated immunity as an independent variable.

Animal models over the last few decades have attempted to approximate human anti-GBM disease $(15,16)$, the optimal binding conditions for antibody $(17,18)$, and the role of accessory molecules (19-21) or amplification mechanisms like the activation of complement (22). Unfortunately, these studies were performed before much was known about the specificity of the antibodies in human anti-GBM disease $(3,4)$ or in animal models that only mimic a portion of the disease seen in patients $(4,16)$. Furthermore, the tradition of calling anti-GBM nephritis an antibody-mediated disease has tempered greatly work evaluating the likely role of cellular immunity in its pathogenesis.

Immunization with crude GBM, or transfer of heterologous antibodies to crude GBM, produces a form of anti-GBM disease $(15,22)$ in monkeys, sheep, rabbits, and rats, but gives mixed results in mice (23-25). Initiation of nephritis with crude antigen, of course, does not reflect the more focused response typical of the human condition, that of antibodies directed to a single antigen like the $\alpha 3$ (IV) NC1 domain $(4,26)$. Surprisingly, however, earlier attempts to produce aggressive disease with $\alpha 3$ (IV) NC1 collagen in rabbits were only partially successful (27). Perhaps this was because the outbred rabbits did not carry MHC haplotypes fully favoring progressive injury.

The mouse model reported here is a significant advance over previous work because it comes much closer to the variable presentation of human anti-GBM disease, uses a single protein as antigen, and, with the availability of inbred and recombinant mice, lends itself to the segregation of important immunogenetic traits.

1. Abbreviations used in this paper: ABM, alveolar basement membrane; GPS, Goodpasture syndrome; TcR, T cell receptor. 


\section{Methods}

Immunization of mice with $\alpha 3(\mathrm{IV}) \mathrm{NC1}$ domains. Inbred and recombinant mice SJL/J (H-2 $\left.{ }^{\mathrm{s}}\right)$, C57BL/6J (B6; H-2 $)$, C57BL/10SnJ (B10; $\left.\mathrm{H}-2^{\mathrm{b}}\right), \mathrm{BALB} / \mathrm{cJ}\left(\mathrm{H}-2^{\mathrm{d}}\right), \mathrm{DBA} / 2 \mathrm{~J}\left(\mathrm{H}-2^{\mathrm{d}}\right), \mathrm{A} / \mathrm{J}\left(\mathrm{H}-2^{\mathrm{a}}\right), \mathrm{B} 10 . \mathrm{A} / \mathrm{SgSnJ}$ $\left(\mathrm{H}-2^{\mathrm{a}}\right), \mathrm{AKR} / \mathrm{J}\left(\mathrm{H}-2^{\mathrm{k}}\right), \mathrm{CBA} / \mathrm{J}\left(\mathrm{H}-2^{\mathrm{k}}\right), \mathrm{A} . \mathrm{SW} / \mathrm{SnJ}\left(\mathrm{H}-2^{\mathrm{s}}\right)$, A.TL/Sf$\operatorname{DvEg}\left(\mathrm{H}-2^{\mathrm{t} 1}\right), \mathrm{B} 10 . \mathrm{S} / \mathrm{J}\left(\mathrm{H}-2^{\mathrm{s}}\right),(\mathrm{BALB} \times \mathrm{A} / \mathrm{J}) \mathrm{F} 1,(\mathrm{BALB} \times \mathrm{DBA} / 2)$ F1, B10.BR/SgSnJ $\left(\mathrm{H}-2^{\mathrm{k}}\right)$, and C57BL/6J-Tcrb ${ }^{\text {tmlMom }} \mathrm{Tcrd}^{\text {tmlMom }}\left(\mathrm{H}-2^{\mathrm{b}}\right)$ $\mathrm{T}$ cell receptor (TcR)-deficient mice were purchased from The Jackson Laboratory (Bar Harbor, ME) at 4-6 wk of age. The $\mathrm{Tcrb}^{\text {tmlMom }} \mathrm{Tcrd}^{\text {tmIMom }}$ TcR-deficient mice express neither $\alpha / \beta$ or $\gamma / \delta$ TcRs (28), and are designated TcR $-/-$ in this report. The B10.S(9R) recombinants were obtained from Dr. Ronald Schwartz (National Institutes of Health, Bethesda, MD) through Contract Grant N01-A0-

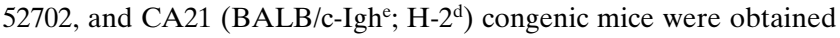
from Dr. Roy Riblet (Molecular Biosystems, Inc., La Jolla, CA). $(\mathrm{A} / \mathrm{J} \times \mathrm{SJL}) \mathrm{F} 1$ and $(\mathrm{BALB} / \mathrm{c} \times \mathrm{CA} 21) \mathrm{F} 1$ crosses were bred at the University of Pennsylvania. Four to six mice in each experimental group were immunized with $25 \mu \mathrm{g}$ of $\alpha 3$ (IV) NC1 collagen subcutaneously in CFA followed by a booster injection 3-4 wk later (29). Control mice were injected with CFA alone. Blood, kidneys, and lung tissues were collected from each mouse at time of killing. Tissues were either snap-frozen for antibody elution or immunolocalization, or fixed in $10 \%$ phosphate saline-buffered formalin for histopathology. Two mice from each group were placed randomly in metabolic cages for $16 \mathrm{~h}$ before time of killing to determine overnight urine protein excretion (29). A serum sample from each mouse was obtained for creatinine measurement (29) and anti- $\alpha 3$ (IV) collagen antibodies by ELISA (26).

Preparation of the antigens. Bovine $\alpha 3$ (IV) NC1 dimers were isolated from bovine testis $(27,30,31)$. Bovine testis was digested with bacterial collagenase, and the collagenase-solubilized material was resolved by gel filtration and reverse-phase HPLC, as described previously $(27,31)$. The isolated $\alpha 3$ (IV) $\mathrm{NC1}$ dimers were characterized by type IV collagen $\alpha$ chain-specific antibodies by ELISA and Western blot before use for the immunization of mice. Mouse $\mathrm{NC} 1$ hexamer was prepared as described for bovine and human NC1 hexamer (31).

Adoptive and passive transfer studies. For passive transfer experiments, $500 \mu l$ of undiluted serum from SJL mice with anti-GBM disease was injected intravenously into naive healthy SJL recipients. For adoptive transfer experiments, spleens and lymph nodes were removed from SJL mice immunized with $\alpha 3$ (IV) NC1 collagen. Lymphocytes prepared from spleen and lymph nodes (32) were injected into naive SJL mice pretreated with cyclophosphamide $(20 \mathrm{mg} / \mathrm{kg}) 48 \mathrm{~h}$ before the transfer. Each SJL recipient received $10^{8}$ lymphocytes by intravenous injection. The control mice received lymphocytes from CFA-injected mice.

Histopathology and immunofluorescence. Tissue fixed in 10\% buffered formalin were sectioned and stained with periodic acidSchiff (PAS) and/or hematoxylin and eosin. Frozen tissues were cryostat-sectioned and stained with FITC-conjugated rabbit anti-mouse IgG, IgM, IgA, and C3 (Sigma Chemical Co., St. Louis, MO). All the sections were viewed blind in at least 10 fields using a microscope (Carl Zeiss, Inc., Thornwood, NY) with appropriate excitation filters (29). Tissues fixed in $10 \%$ buffered formalin were also stained with primary goat antibodies directed to IL-12 and IL-4 (R \& D Systems, Inc., Minneapolis, MN) and developed with a secondary rabbit antigoat antibody linked to horseradish peroxidase (33).

ELISA. For direct ELISA, the plates were coated in triplicate with $100 \mathrm{ng}$ of antigen in $200 \mu \mathrm{l}$ of coating buffer. The plates were incubated for $2 \mathrm{~h}$ at $37^{\circ} \mathrm{C}$ or overnight at room temperature. Upon coating, the plates were washed three times at intervals of 5 min with $0.15 \mathrm{M}$ $\mathrm{NaCl}$ and $0.05 \%$ Tween 20 (washing buffer). After washing, the plates were blocked with $2 \%$ BSA in PBS for $30 \mathrm{~min}$ at $37^{\circ} \mathrm{C}$. Upon blocking, the plates were washed again with the washing buffer and then incubated with primary antibody in appropriate dilution in PBS. The plates were incubated for $1 \mathrm{~h}$ at $37^{\circ} \mathrm{C}$. After primary antibody incubation, the plates were washed again and subsequently incubated with the secondary antibody (anti-mouse IgG) conjugated to alkaline phosphatase at 1:5,000 dilution in PBS. The plates were incubated for $1 \mathrm{~h}$ at $37^{\circ} \mathrm{C}$. Subsequently, the plates were washed again thoroughly, and substrate, disodium $p$-nitrophenyl phosphate $(5 \mathrm{mg} / \mathrm{ml})$, was added. After color development, the absorbance was measured using an ELISA autoreader at $405 \mathrm{~nm}$. The native bovine and human recombinant antigens were prepared as described previously $(26,34)$.

Inhibition ELISA was performed as before $(10,11,27,34)$ with slight modification. The ELISA plates were coated with $100 \mathrm{ng}$ of dissociated mouse $\mathrm{NC} 1$ hexamer in $6 \mathrm{M}$ guanidine- $\mathrm{HCl}, 50 \mathrm{mM}$ Tris- $\mathrm{HCl}$, $\mathrm{pH}$ 7.5. Initially, dilution curves were obtained for the human Goodpasture and mouse antibodies. The plates were coated overnight at room temperature. Upon washing and blocking the plates, as described above for direct ELISA, saturating concentrations of Goodpasture or mouse antibodies were used in the assay. The plates were incubated overnight and developed as described above for direct ELISA.

Antibody elution from the tissue. Antibody elution from the kidneys and lungs was described previously (27). Briefly, the tissue was homogenized in the presence of protease inhibitors and washed thoroughly with distilled water. The resultant pellet was subjected to extraction with $0.1 \mathrm{M}$ glycine, $0.5 \mathrm{M} \mathrm{NaCl}, \mathrm{pH} 2.8$. The extracted material was dialyzed extensively against $10 \mathrm{mM}$ PBS and subsequently precipitated with $40 \%$ ammonium sulfate. The resultant pellet was solubilized in suitable volume of $10 \mathrm{mM}$ PBS for future experiments.

Oral feeding of protein fraction containing $\alpha 3(I V)$ NC1 domain. Mice were gavaged either with 65 or $700 \mu \mathrm{g}$ of BSA or $\alpha 3$ (IV) NC1 dimer-enriched type IV collagen (principally $\alpha 3$, but likely also containing small amounts of $\alpha 1, \alpha 4$, and $\alpha 5$ ) in sterile PBS distributed over 5 alternate day feedings for $10 \mathrm{~d}$ before immunization with the $\alpha 3$ (IV) NC1 domains in adjuvant. The dosages and regimen of feeding were extrapolated from similar studies using other mouse models for autoimmune disease $(35,36)$. The mice were immunized with 25 $\mu \mathrm{g}$ of antigen in CFA and boosted 3 wk later with the same amount in incomplete Freund's adjuvant. 2 mo later, the mice were evaluated for renal function, and their blood and tissue were harvested for serological analysis and histopathology.

\section{Results}

Mice in this study were immunized with the GPS antigen in adjuvant (CFA) made from purified bovine $\alpha 3$ (IV) NC1 collagen $(27,30)$ and the resulting immune response produced antiGBM antibodies cross-reactive with human antibodies from Goodpasture patients, lung hemorrhage, crescentic glomerulonephritis, and progressive renal failure in susceptible haplotypes.

Characterization of anti-GBM disease in mice. 8 different inbred strains of mice reflecting a diversity of $\mathrm{MHC}$ haplotypes were selected for immunization with $\alpha 3$ (IV) NC1 domains (Table I). 12 wk later, SJL mice (H-2 $)$ emerged as strong nephritic responders, with the highest urine protein, followed by the moderate responders, B6 $\left(\mathrm{H}-2^{\mathrm{b}}\right), \mathrm{BALB} / \mathrm{c}\left(\mathrm{H}-2^{\mathrm{d}}\right)$, and DBA/2 (H-2 $\left.{ }^{\mathrm{d}}\right) . \mathrm{A} / \mathrm{J}\left(\mathrm{H}-2^{\mathrm{a}}\right), \operatorname{AKR}\left(\mathrm{H}-2^{\mathrm{k}}\right)$, and CBA $\left(\mathrm{H}-2^{\mathrm{k}}\right)$ were nonnephritic and had normal levels of urine protein. The levels of renal failure as measured by serum creatinine in all groups reflected the trends set by the urine protein data; the nonnephritic mice had normal levels.

All mice injected with $\alpha 3$ (IV) NC1 domains developed high titers of circulating anti- $\alpha 3$ (IV) NC1 antibodies regardless of whether they developed cellular infiltrates and renal injury, suggesting that the intensity of the antibody response is not a selective determinant of susceptibility to disease (Fig. 1 $A$ ). The circulating, kidney-, and lung-bound antibodies from SJL mice were quite specific for native bovine and recombi- 
Table I. Mice Immunized to Produce Anti-GBM Disease

\begin{tabular}{|c|c|c|c|c|c|c|c|c|c|c|c|c|c|c|}
\hline Strain* & $\mathrm{H}-2$ & $\mathrm{~K}$ & $\mathrm{~A} \beta$ & $\mathrm{A} \alpha$ & $\mathrm{E} \beta$ & $\mathrm{E} \alpha^{\ddagger}$ & D & UP & $\mathrm{sCr}$ & $\alpha 3(\mathrm{IV}) \mathrm{Ab}$ & $\mathrm{cGN}$ & TIN & IF-Kidney & IF-Lung \\
\hline & & & & & & & & $m g / 16 h$ & $m g / d l$ & & $\%$ & & & \\
\hline SJL & $\mathrm{s}$ & $\mathrm{S}$ & $\mathrm{s}$ & $\mathrm{s}$ & - & - & s & $16.5 \pm 6.3$ & $4.20 \pm 1.6$ & + & 45 & 4 & + & + \\
\hline $\mathrm{BALB} / \mathrm{c}$ & $\mathrm{d}$ & d & d & d & d & d & d & $6.70 \pm 1.3$ & $3.00 \pm 1.1$ & + & 12 & 3 & + & + \\
\hline $\mathrm{DBA} / 2$ & d & d & d & d & d & d & d & $2.11 \pm 1.1$ & $3.20 \pm 1.4$ & + & 22 & 2 & + & - \\
\hline B6 & $\mathrm{b}$ & $\mathrm{b}$ & $\mathrm{b}$ & $\mathrm{b}$ & - & - & $\mathrm{b}$ & $5.00 \pm 2.1$ & $3.20 \pm 1.3$ & + & 20 & 2 & + & + \\
\hline CBA & $\mathrm{k}$ & $\mathrm{k}$ & $\mathrm{k}$ & $\mathrm{k}$ & $\mathrm{k}$ & $\mathrm{k}$ & $\mathrm{k}$ & $1.90 \pm 0.8$ & $1.20 \pm 0.8$ & + & $<0.5$ & 0 & + & \pm \\
\hline $\mathrm{A} / \mathrm{J}$ & $\mathrm{a}$ & $\mathrm{k}$ & $\mathrm{k}$ & $\mathrm{k}$ & $\mathrm{k}$ & $\mathrm{k}$ & d & $1.20 \pm 0.5$ & $0.65 \pm 0.4$ & + & $<0.5$ & 0 & + & - \\
\hline AKR & $\mathrm{k}$ & $\mathrm{k}$ & $\mathrm{k}$ & $\mathrm{k}$ & $\mathrm{k}$ & $\mathrm{k}$ & $\mathrm{k}$ & $0.4 \pm 0.0$ & $0.85 \pm 0.2$ & + & $<0.5$ & 0 & + & - \\
\hline Controls & & & & & & & & $1.00 \pm 0.8$ & $0.90 \pm 0.7$ & - & 0 & 0 & - & - \\
\hline
\end{tabular}

$* n=4-12$ mice in each group; controls include 2 mice from each strain. ${ }^{\star} \mathrm{mRNA}$ for E $\alpha$ in SJL and B6 mice is not transcribed, hence the E $\alpha / \mathrm{E} \beta$ heterodimer protein is also not expressed on cell surface. Protein and serum creatinine measurements were made separately for each group. $U P$, Urine protein (27). $s C r$, Serum creatinine (29). $c G N$, Crescentic glomerulonephritis, as measured by percent fully developed crescentic glomeruli. TIN, Tubulointerstitial nephritis, estimated by scale (29); 4 is highest and 0 is absent. IF, Immunofluorescence (27).

nant human $\alpha 3$ (IV) NC1 domain (Fig. 1, $B$ and $C$ ). Antibodies from $\mathrm{A} / \mathrm{J}$ mice also had some minor additional reactivity to $\alpha 1$ and $\alpha 2$ (IV) NC1 domains of type IV collagen (data not shown).

Histopathological examination of kidneys from nephritic mice revealed severe crescentic glomerulonephritis with considerable tubulointerstitial disease (Table I and Fig. 2). SJL mice with anti-GBM disease had full to partial crescents in $45 \%$ of their glomeruli, compared with none in the nonresponder mice, and $20-22 \%$ in B6 and DBA/2 mice (Table I). In the SJL mice, most of the glomeruli revealed cellular infiltrates and shrinkage. Mononuclear infiltrates were evident in glomeruli and in the renal interstitium (Fig. $2 A$ ). Lung sections from these mice also contained focal to massive hemorrhage with extravasation of red blood cells into alveolar air spaces (Fig. 2 B). Kidney and lung sections from A/J, AKR, and CBA mice appeared normal and comparable to CFA controls.

Cell-mediated susceptibility genes permissive for anti-GBM disease. Age-matched recombinant and congenic mice were used to characterize further the role of individual polymor- phisms at class I and class II MHC loci for their effect on the expression of murine anti-GBM disease (Table II).

8 wk after immunization, A/J, A.TL, B10.A, and B10.BR mice did not have significant increases in urine protein or serum creatinine levels, compared with CFA-injected control mice (Table II). Histopathological evaluation of kidneys and lungs in these animals also revealed no tissue abnormalities. However, at the same time point, SJL, B6, B10, B10.S, B10.S(9R), and A.SW mice demonstrated an increase in urine protein (Table II). Serum creatinine was also elevated when analyzed 12 wk after initial immunization. Kidney and lung tissue revealed varying degrees of crescentic glomerulonephritis with tubulointerstitial disease and linear binding of $\mathrm{IgG}$ on the GBM.

The presence or absence of glomerulonephritis among B10, B10.S, B10.S(9R), B10.BR, and B10.A recombinant mice indicates that glomerular inflammation is linked to a subregion of the MHC; differences among SJL, A.SW, and A/J mice were confirmatory. Comparisons of BALB/c, A/J, B10.K, and B10.A mice suggest that the class I/D region of the mouse $\mathrm{H}-2$ is not relevant. The differences in disease among SJL, A.SW,

Table II. MHC Recombinant Mice Immunized to Produce Anti-GBM Disease

\begin{tabular}{|c|c|c|c|c|c|c|c|c|c|c|c|c|c|}
\hline Strain* & $\mathrm{H}-2$ & $\mathrm{~K}$ & $\mathrm{~A} \beta$ & $\mathrm{A} \alpha$ & $\mathrm{E} \beta$ & $E \alpha^{\ddagger}$ & $\mathrm{D}$ & UP & $\mathrm{sCr}$ & $\alpha 3(\mathrm{IV}) \mathrm{Ab}$ & $\mathrm{cGN}$ & TIN & IF-Lung \\
\hline & & & & & & & & $m g / 16 h$ & $m g / d l$ & & $\%$ & & \\
\hline SJL & $\mathrm{S}$ & $\mathrm{s}$ & $\mathrm{S}$ & $\mathrm{s}$ & - & - & $\mathrm{s}$ & $10.8 \pm 2.8$ & $3.12 \pm 1.2$ & + & 29 & 3 & + \\
\hline A.SW & $\mathrm{S}$ & $\mathrm{s}$ & $\mathrm{s}$ & $\mathrm{s}$ & - & - & $\mathrm{s}$ & $9.00 \pm 1.7$ & $2.51 \pm 1.4$ & + & 16 & 2 & + \\
\hline A.TL & $\mathrm{t} 1$ & $\mathrm{~s}$ & $\mathrm{k}$ & $\mathrm{k}$ & $\mathrm{k}$ & $\mathrm{k}$ & $\mathrm{d}$ & $1.18 \pm 0.9$ & $0.85 \pm 0.5$ & + & 6 & 0 & - \\
\hline $\mathrm{A} / \mathrm{J}$ & $\mathrm{a}$ & $\mathrm{k}$ & $\mathrm{k}$ & $\mathrm{k}$ & $\mathrm{k}$ & $\mathrm{k}$ & $\mathrm{d}$ & $1.32 \pm 1.1$ & $0.91 \pm 0.6$ & + & 2 & 0 & - \\
\hline B10.S & $\mathrm{s}$ & $\mathrm{s}$ & $\mathrm{s}$ & $\mathrm{s}$ & - & - & $\mathrm{s}$ & $8.90 \pm 2.3$ & $2.80 \pm 1.1$ & + & 18 & 2 & + \\
\hline B10 & $\mathrm{b}$ & $\mathrm{b}$ & b & $\mathrm{b}$ & - & - & $\mathrm{b}$ & $4.90 \pm 1.3$ & $1.85 \pm 0.7$ & + & 19 & 1.5 & + \\
\hline B10.S(9R) & $\mathrm{t} 4$ & $\mathrm{~s}$ & $\mathrm{~s}$ & $\mathrm{~s}$ & $\mathrm{~s}$ & $\mathrm{k}$ & d & $7.30 \pm 1.5$ & $1.71 \pm 0.1$ & + & 10 & 1.5 & + \\
\hline B10.BR & $\mathrm{k}$ & $\mathrm{k}$ & $\mathrm{k}$ & $\mathrm{k}$ & $\mathrm{k}$ & $\mathrm{k}$ & $\mathrm{k}$ & $1.50 \pm 0.1$ & $0.61 \pm 0.2$ & + & 3 & 1 & - \\
\hline B10.A & $\mathrm{a}$ & $\mathrm{k}$ & $\mathrm{k}$ & $\mathrm{k}$ & $\mathrm{k}$ & $\mathrm{k}$ & $\mathrm{d}$ & $1.46 \pm 0.1$ & $0.81 \pm 0.0$ & + & 5 & 0 & - \\
\hline Controls & & & & & & & & $1.40 \pm 1.1$ & $0.80 \pm 0.7$ & - & 0 & 0 & - \\
\hline
\end{tabular}

${ }^{*} n=4$ mice in each group; controls include 2 mice from each strain. ${ }^{\ddagger} \mathrm{mRNA}$ for E $\alpha$ in SJL and B6 mice is not transcribed, hence the E $\alpha / \mathrm{E} \beta$ heterodimer protein is also not expressed on cell surface. Protein and serum creatinine measurements were made separately for each group. $U P$, Urine protein (27). $s C r$, Serum creatinine (29). $c G N$, Crescentic glomerulonephritis, as measured by percent fully developed crescentic glomeruli. $T I N$, Tubulointerstitial nephritis, estimated by scale (29); 4 is highest and 0 is absent. IF, Immunofluorescence (27). 

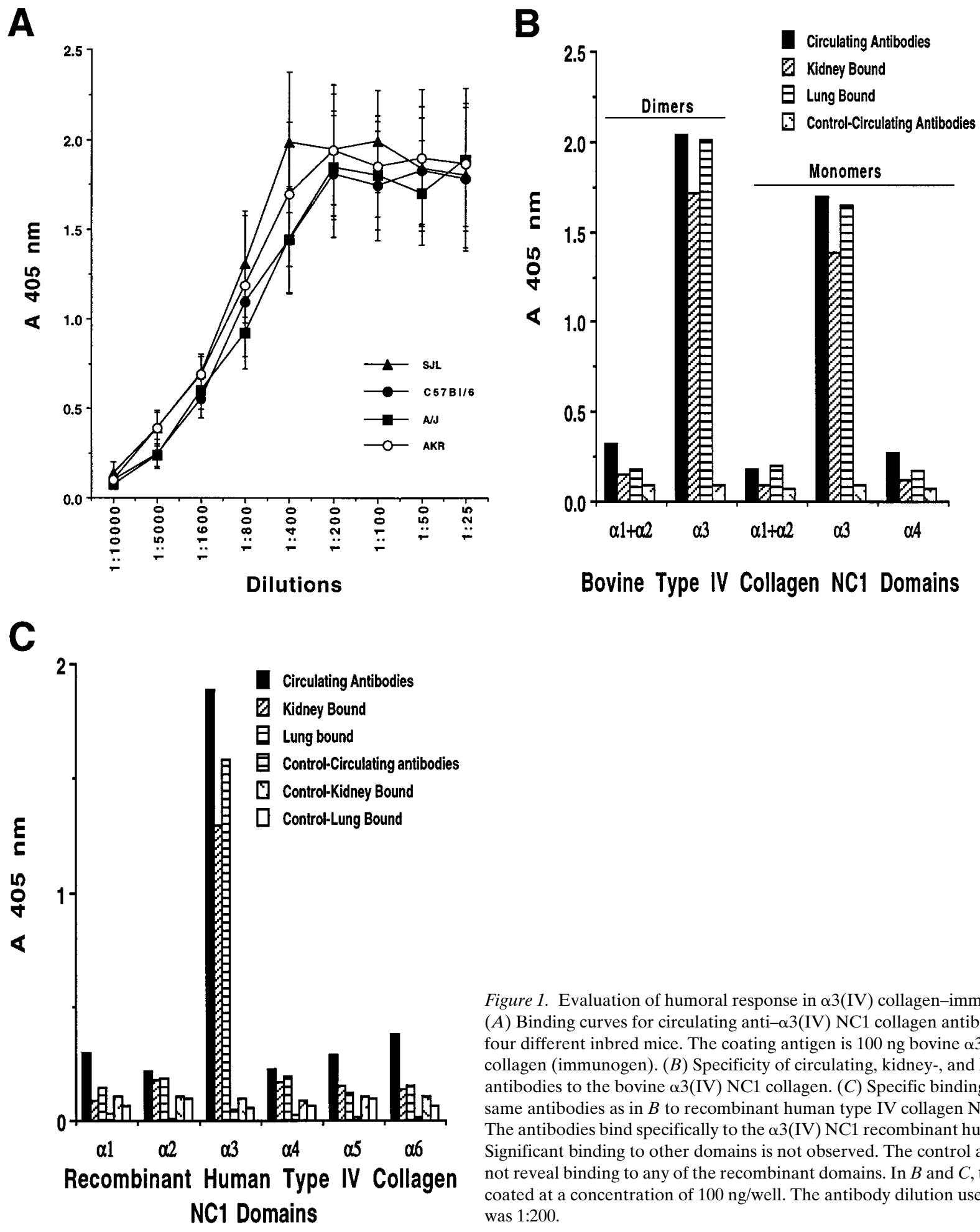

Figure 1. Evaluation of humoral response in $\alpha 3(\mathrm{IV})$ collagen-immunized mice. (A) Binding curves for circulating anti- $\alpha 3$ (IV) NC1 collagen antibodies from four different inbred mice. The coating antigen is $100 \mathrm{ng}$ bovine $\alpha 3$ (IV) NC1 collagen (immunogen). (B) Specificity of circulating, kidney-, and lung-bound antibodies to the bovine $\alpha 3$ (IV) NC1 collagen. ( $C$ ) Specific binding of the same antibodies as in $B$ to recombinant human type IV collagen $\mathrm{NC1}$ domain. The antibodies bind specifically to the $\alpha 3$ (IV) NC1 recombinant human antigen. Significant binding to other domains is not observed. The control antibodies do not reveal binding to any of the recombinant domains. In $B$ and $C$, the antigen is coated at a concentration of $100 \mathrm{ng} / \mathrm{well}$. The antibody dilution used in $B$ and $C$ was $1: 200$.

and A.TL mice indicate further that the class $\mathrm{I} / \mathrm{K}$ region is also not important. Therefore, it is quite likely that some $A \beta / A \alpha$ haplotypes are linked to important susceptibility genes mediating cellular reactions in glomeruli and the interstitium, since theE-regiongeneproductsofMHCclassIlarenotexpressedin H-2,b haplotypes (37), and since A.SW, B10.S, and B10.S(9R) mice are susceptible to anti-GBM disease, whereas A.TL mice are not.
Immunofluorescent staining for immunoglobulin in tissues. Linear binding of IgG along the GBM and alveolar basement membrane $(\mathrm{ABM})$ of immunized animals was observed by immunofluorescent staining on frozen kidney and lung sections (Fig. 2, $C$ and $D$, respectively). Control SJL mice appeared normal, with no overt histopathological changes or specific IgG binding in the kidney or lung. IgA and IgM staining in the GBM and ABM was not noted in either the experimental or 

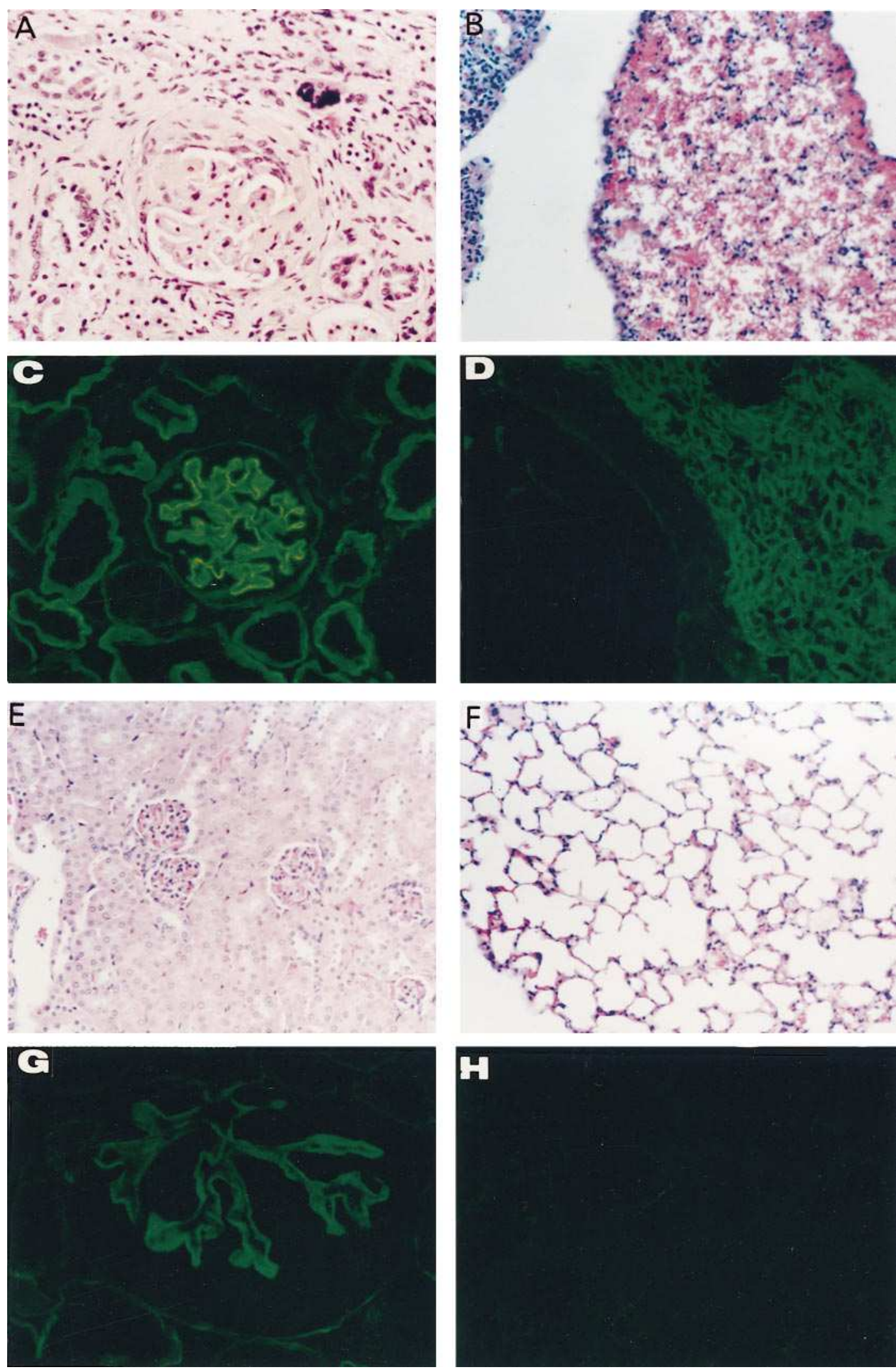

Figure 2. Immunohistochemical analysis of lung and kidney tissue of $\alpha 3(\mathrm{IV})$ collagen-inbred mice. 4- $\mu \mathrm{m}$ sections of paraffin-embedded kidney and lung sections were stained with hematoxylin and eosin for histopathological analysis by light microscopy. 5-6- $\mu \mathrm{m}$ sections of OCT-embedded frozen tissues of kidney and lung were prepared for immunofluorescence studies. $(A)$ Light-microscope evaluation of hematoxylin and eosin-stained kidney from SJL mice immunized with $\alpha 3$ (IV) collagen. (B)

Light-microscope evaluation of hematoxylin and eosin-stained lung from SJL mice immunized with $\alpha 3$ (IV) collagen. (C) Immunofluorescent evaluation for endogenous mouse IgG in kidney of SJL mice immunized with $\alpha 3$ (IV) collagen. $(D)$ Immunofluorescent evaluation for endogenous mouse IgG in lung of SJL mice immunized with $\alpha 3$ (IV) collagen. Notice the selective staining of the ABM in the alveolus with no significant staining in the bronchial side. $(E)$ Normal-appearing kidney of $\mathrm{A} / \mathrm{J}$ mice immunized with $\alpha 3$ (IV) collagen. $(F)$ Normal-appearing lung of $\mathrm{A} / \mathrm{J}$ mice immunized with $\alpha 3$ (IV) collagen. ( $G$ and $H$ ) Immunofluorescent pictures of kidney and lung sections from $\mathrm{A} / \mathrm{J}$ mice immunized with $\alpha 3(\mathrm{IV})$ collagen. The kidney reveals linear binding of mouse IgG on the GBM, with occasional tubular staining. The lung does not reveal any IgG localization.

control mice (data not shown). C3 staining was observed as patchy immunofluorescence along the GBM of SJL mice with anti-GBM disease, as well as in $\mathrm{A} / \mathrm{J}$ mice without glomerular pathology. B6 and DBA/2 mice also presented with similar im- munofluorescent staining in the kidney as SJL mice, in spite of their less intense renal disease (data not shown).

Kidney sections from A/J, AKR, and CBA mice that did not develop cellular injury demonstrated the same linear bind- 


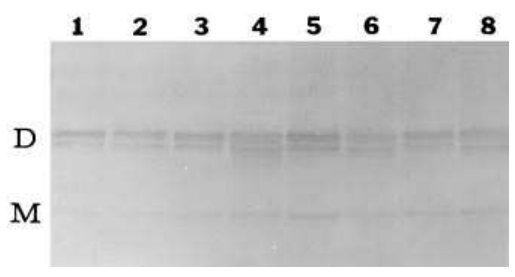

Figure 3. Immunoblot analysis of Goodpasture antigen $[\alpha 3(\mathrm{IV})$ collagen] in the kidney and lung tissue from mice. Lungs from eight naive mice of each inbred strain were used for bacterial collagenase digestion to extract the NC1 domain of type IV collagen. $15 \mu \mathrm{g}$ of the digest was analyzed by SDS-PAGE and immunoblotting with human Goodpasture antisera (31). These antibodies recognize specifically the $\alpha 3$ (IV) NC1 domain (Goodpasture antigen). $D$ and $M$, The dimers and monomers, respectively, of NC1 domain that are recognized by the Goodpasture antibodies (31). The molecular masses of the dimers and monomers are $\sim 54$ and $28 \mathrm{kD}$, respectively. Lanes 1 and 2 denote SJL, lanes 3 and 4 denote DBA/2, lanes 5 and 6 denote $\mathrm{A} / \mathrm{J}$, lanes 7 and 8 denote $(\mathrm{A} / \mathrm{J} \times \mathrm{SJL}) \mathrm{F} 1$. Lanes 1,3 , and 5 are kidney $\mathrm{NC} 1$, and lanes 2, 4, 6, and 8 are lung NC1. The two bands in the monomer region could represent two size isoforms of $\alpha 3$ (IV) NC1 monomer (67).

ing of mouse $\mathrm{IgG}$ to the GBM as was observed in nephritic mice, although no mouse IgG was localized on the ABM in the lung (Table I; Fig. 2, $G$ and $H$, respectively). Furthermore, $\mathrm{DBA} / 2$ mice, unlike BALB/c, A/J, and $(\mathrm{A} / \mathrm{J} \times \mathrm{SJL}) \mathrm{F} 1$ mice, respond to immunization with $\alpha 3(\mathrm{IV}) \mathrm{NC1}$ domain, with disease limited to the kidneys. DBA/2 mouse lungs had no inflammation present and lacked anti- $\alpha 3$ (IV) $\mathrm{NC1}$ antibodies along the ABM (Table I). However, ABMs in normal lung tissue from $\mathrm{DBA} / 2$ and $\mathrm{A} / \mathrm{J}$ mice stained in a linear pattern with isogenic anti-GBM antibodies by indirect immunofluores- cence after preincubation of the tissue with acetone (data not shown). These results suggest that, in some strains, the Goodpasture antigen in ABM compared with GBM is more cloaked and less available for binding by anti- $\alpha 3$ (IV) NC1 antibodies.

$\mathrm{ABM}$ and kidney basement membrane from SJL, A.SW, $(\mathrm{A} / \mathrm{J} \times \mathrm{SJL}) \mathrm{F} 1, \mathrm{~A} / \mathrm{J}$, and DBA/2 mice were next digested, and their NC1 hexamers were electrophoresed by SDS-PAGE for Western blotting with anti- $\alpha 3$ (IV) antibody from a patient with GPS (38). Binding was observed to the dimers and monomers of type IV collagen NC1 hexamer. Some additional faint reactivity can be seen, with bands above the dimers, which could represent partially digested type IV collagen protomer. Lung tissue from $\mathrm{DBA} / 2, \mathrm{~A} / \mathrm{J}$, and $(\mathrm{A} / \mathrm{J} \times \mathrm{SJL}) \mathrm{F} 1$ mice that did not bind anti- $\alpha 3$ (IV) NC1 antibody in vivo contained comparable amounts of target antigen by Western blot as the $\mathrm{ABM}$ of SJL mice with lung hemorrhage (Fig. 3). Further immunofluorescent comparisons between A/J versus A.SW and $\mathrm{B} 10$ versus $\mathrm{B} 10$. A mice indicate that antibody binding to the $\alpha 3(\mathrm{IV}) \mathrm{NC1}$ domain in ABM in vivo maps as a polymorphism for structural visibility (Table II). The immunologic privilege from invisibility of $\alpha 3$ (IV) collagen in ABM is also linked to MHC genes, and comparisons of A/J, A.TL, A.SW, B10, B10.A, B10.S, and B10.S(9R) suggest that this effect may map to the $A \beta / A \alpha$ region of $H-2$; the absence of binding of $A B M$ in the $(\mathrm{A} / \mathrm{J} \times \mathrm{SJL}) \mathrm{F} 1$ crosses indicates further that the protective effect in $\mathrm{A} / \mathrm{J}$ is dominant. This latter observation in $\mathrm{H}-2^{\mathrm{a}}$ was confirmed in $(\mathrm{A} / \mathrm{J} \times \mathrm{BALB} / \mathrm{c}) \mathrm{F} 1$ crosses (data not shown).

Serological comparison of the anti- $\alpha 3(I V)$ NC1 collagen antibody repertoire in mice and humans. The 8 inbred strains of mice injected with $\alpha 3$ (IV) collagen and described in Table I all developed antibodies to $\alpha 3$ (IV) NC1 domains. Anti- $\alpha 3$ (IV) $\mathrm{NC} 1$ collagen antibodies in serum were detected starting at
A

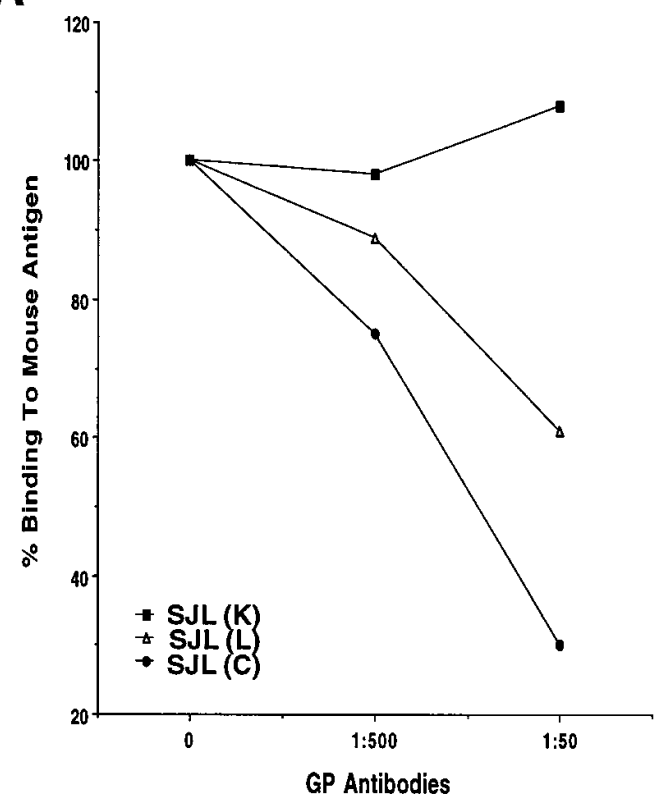

B

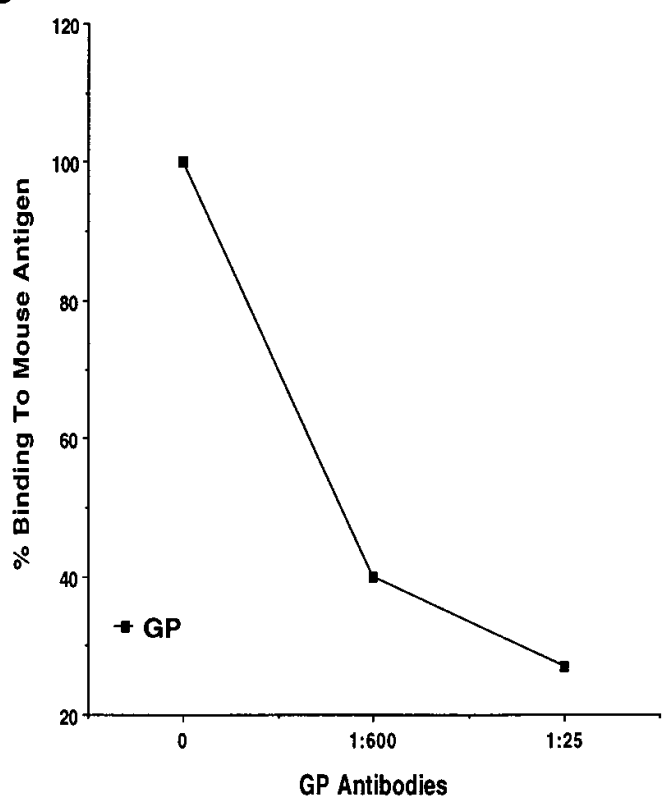

Figure 4. Epitope recognition of murine and human anti- $\alpha 3$ (IV) NC1 collagen antibodies. Binding curves for the human Goodpasture $(G P)$ antibodies, circulating, kidney-, and lung-bound, from SJL mice immunized with bovine $\alpha 3$ (IV) $\mathrm{NC} 1$ collagen were obtained using denatured mouse $\mathrm{NC1}$ hexamer as the coating antigen in direct ELISA. The 50 and $100 \%$ saturating human Goodpasture antibody concentrations were used as inhibitor to binding of the mouse antibodies to mouse antigen. $(A)$ Inhibition curves from such experiments. The assay is developed using antimouse IgG conjugated to alkaline phosphatase.

(B) The reciprocal experiment, in which mouse circulating anti- $\alpha 3$ (IV) NC1 collagen antibodies are used as inhibitor to binding of the human Goodpasture antibodies to mouse antigen. The assay is developed using anti-human IgG conjugated to alkaline phosphatase. In $B$, the 50 and $100 \%$ saturating concentrations for mouse circulating antibodies are 1:600 and 1:25, respectively. The concentration of denatured mouse NC1 hexamer used to coat the wells in all the experiments is $150 \mathrm{ng}$. 
day 7 in susceptible SJL mice, and persisted in high titer until the end of the study (data not shown). Circulating anti- $\alpha 3$ (IV) $\mathrm{NC1}$ antibodies from SJL mice with nephritis stained GBM from human kidney by indirect immunofluorescence (data not shown).

Circulating SJL mouse antisera or antibody eluted from mouse lungs and kidneys were used to compete with human Goodpasture antibody for recognition of dissociated mouse $\mathrm{NC1}$ hexamer. Antibodies eluted from SJL kidney, lung, or the circulation all exhibited $>60 \%$ inhibition of human Goodpasture antibodies to the mouse hexamer (Fig. $4 A$ ). Conversely, human Goodpasture antibodies inhibited the binding of antibody eluted from mouse kidney by $65 \%$, and that from lung by $42 \%$, but little inhibition was observed with circulating antibodies (Fig. $4 \mathrm{~B}$ ). These latter results suggest that anti- $\alpha 3$ (IV)
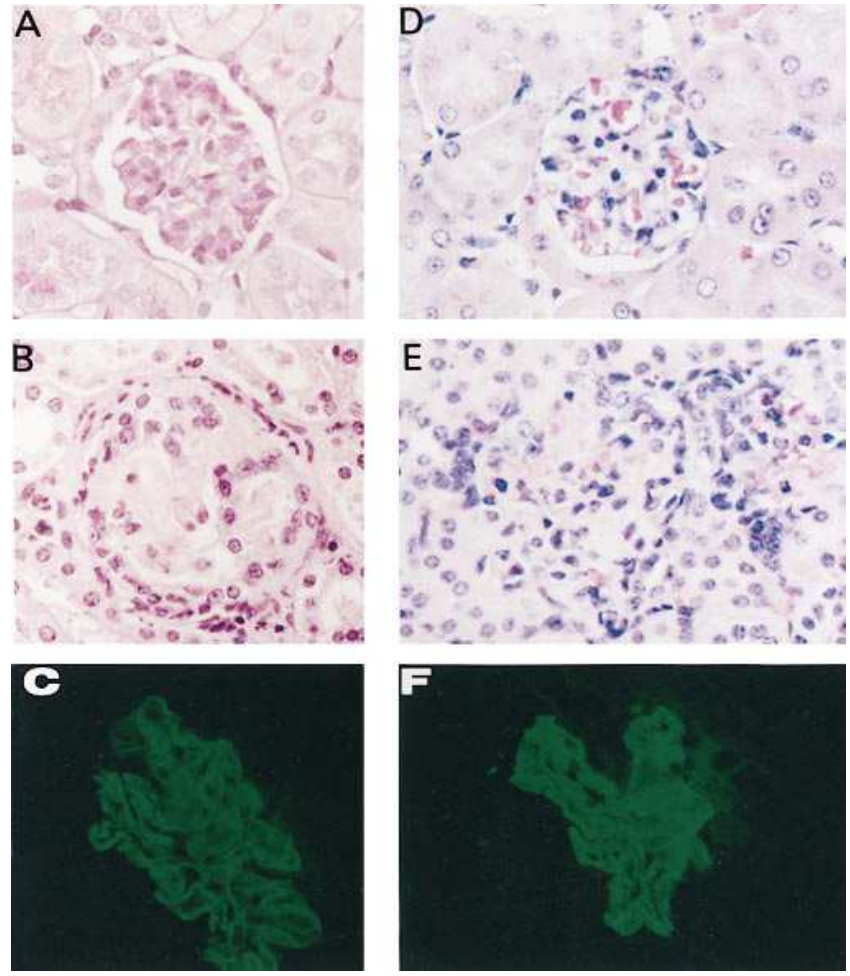

Figure 5. Immunohistopathological evaluation of tissue from passive and adoptive transfer experiments. (A) Hematoxylin and eosinstained kidney section with normal-appearing glomeruli and surrounding tissue from naive SJL mice administered with control sera from CFA-injected SJL mice. (B) Passive transfer of $\alpha 3$ (IV) NC1 collagen sera from mice immunized with $\alpha 3$ (IV) collagen. The hematoxylin and eosin-stained section reveals crescentic glomeruli with tubulointerstitial infiltrates. $(C)$ Immunofluorescent staining for mouse IgG in SJL mice administered with $\alpha 3$ (IV) $\mathrm{NC1}$ sera. Note the linear binding of the $\mathrm{IgG}$ to the GBM and absence of binding to the tubular basement membrane. $(D)$ Hematoxylin and eosin-stained kidney section from cyclophosphamide-treated SJL mice administered with immune cells from spleen and lymph nodes of CFA-injected SJL mice. The kidney appears normal. $(E)$ Kidney section from cyclophosphamide-treated SJL mice that received immune cells from spleen and lymph nodes of SJL mice immunized with $\alpha 3$ (IV) NC1 collagen. Infiltration of immune cells in the glomeruli and the interstitium is observed. $(F)$ Linear binding of mouse IgG in the kidney section from mice described in $E$.
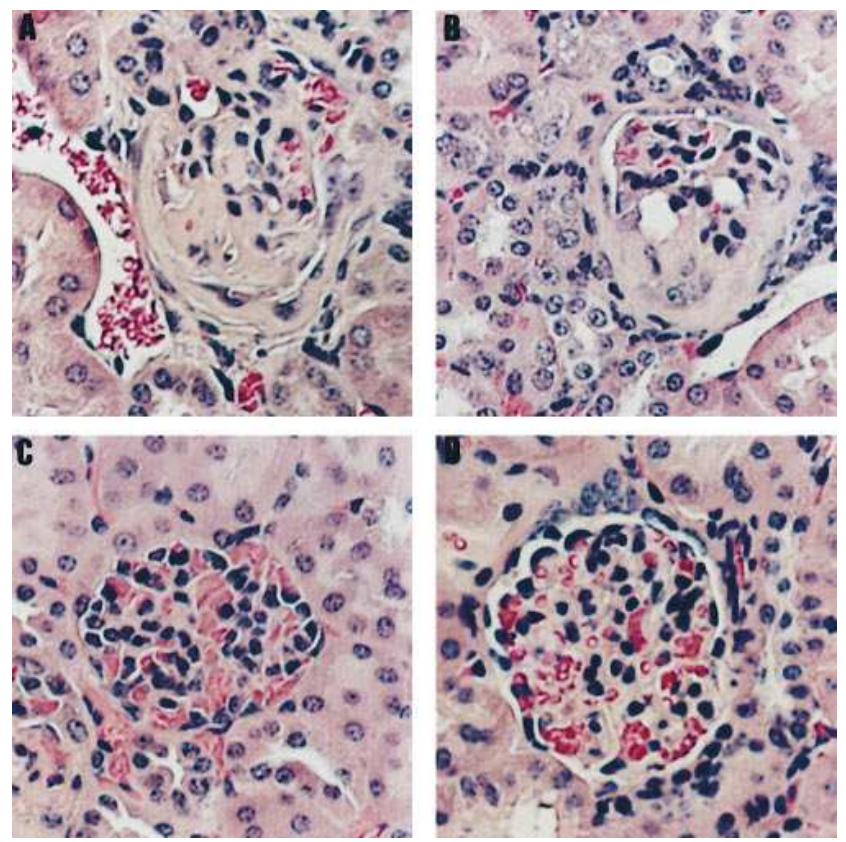

Figure 6. Kidney histology from experiments with TcR-deficient mice. Histological examination of paraffin-embedded 5- $\mu \mathrm{m}$ kidney sections was performed at $3 \mathrm{wk}$ on $-/-$ and $+/+\alpha / \beta$ and $\gamma / \delta$ TcR mice either immunized with $\alpha 3$ (IV) NC1 domains or passively transferred with anti- $\alpha 3$ (IV) NC1 antibodies. $(A)+/+$ mice immunized with $\alpha 3$ (IV) NC1 domains. Urine protein, $5.43 \pm 1.22 \mathrm{mg} / 16 \mathrm{~h}$. (B) Passive transfer of $\alpha 3$ (IV) NC1 antibodies to C57BL/6 mice. Urine protein, $3.78 \pm 1.01 \mathrm{mg} / 16 \mathrm{~h}$. $(C)-/-$ mice immunized with $\alpha 3$ (IV) $\mathrm{NC} 1$ domains. Urine protein, $0.54 \pm 0.12 \mathrm{mg} / 16 \mathrm{~h}$. (D) Passive transfer of $\alpha 3$ (IV) NC1 antibodies into $-/-$ recipient mice. Urine protein, $0.44 \pm 0.11 \mathrm{mg} / 16 \mathrm{~h} .+/+$ kidneys at $3 \mathrm{wk}$ revealed glomerulonephritis with $15 \%$ glomerular crescents and several areas of interstitial infiltrates.

$\mathrm{NC} 1$ antibodies bound to tissue share some target epitopes with human antibodies.

Passive transfer of anti- $\alpha 3(I V) N C 1$ antibodies. Antisera against anti- $\alpha 3$ (IV) NC1 domains were harvested and pooled from SJL mice immunized to produce anti-GBM disease. AntiGBM or control antibodies were passively transferred into naive syngeneic recipients. Urine protein for all the experimental and control mice was monitored on day 3 after transfer. All the experimental SJL mice showed slightly elevated urine protein compared with vehicle-injected controls. On day 5, an experimental SJL mouse was killed, and the tissue was analyzed. The day 5 kidney exhibited some mild inflammation within the glomeruli, with minimal interstitial changes; lung histopathology was normal (data not shown). Immunofluorescent studies revealed linear staining for IgG on the GBM (data not shown). $3 \mathrm{wk}$ after the injection, one experimental SJL mouse died, and the rest of the mice were killed. Histopathology of harvested kidneys revealed several crescentic glomeruli with mononuclear cell infiltrates (Fig. 5, $A$ and $B$ ). The interstitium was inflamed focally with perivascular infiltrates. Immunofluorescent studies on kidney sections showed linear IgG binding to the GBM (Fig. 5 C). These results suggest that anti-GBM disease can be passively transferred to naive SJL mice by administration of anti- $\alpha 3$ (IV) $\mathrm{NC1}$ collagen antibodies. 
Since passive transfer of antibodies into a naive recipient of a susceptible strain produced nephritis, we decided to evaluate the nephritogenic capacity of anti- $\alpha 3$ (IV) NC1 antibodies transferred from a nonsusceptible strain into allotypically compatible recipients. However, when anti- $\alpha 3$ (IV) antibodies from immune $\mathrm{SJL}$ and $\mathrm{A} / \mathrm{J}$ mice were passively transferred into $(\mathrm{A} / \mathrm{J} \times \mathrm{SJL}) \mathrm{F} 1$ recipients, neither produced an expected nephritis. The F1 crosses were then immunized to produce anti-GBM disease, and while robust titers of anti- $\alpha 3$ (IV) antibodies appeared (data not shown), there was still no nephritis.

MHC-identical F1 crosses between disease-susceptible $\mathrm{BALB} / \mathrm{c}$ and congenic CA21 mice (BALB.Igh ${ }^{\mathrm{e}}$ ) were next generated and used as recipients to test the nephritogenicity of passively transferred anti- $\alpha 3$ (IV) collagen antibodies from disease-susceptible BALB/c and nonsusceptible A/J mice. The development of antiallotype antibodies against the $\mathrm{A} / \mathrm{J}\left(\mathrm{Igh}^{\mathrm{e}}\right)$ allotype was avoided by using congenic CA21 (BALB.Ighe) mice in the cross $(39,40) .3 \mathrm{wk}$ after the passive transfer of immune sera from $\mathrm{BALB} / \mathrm{c}$ or $\mathrm{A} / \mathrm{J}$ mice into the $(\mathrm{BALB} / \mathrm{c} \times$ CA21) F1 recipients, we observed that both sets of antibodies produced anti-GBM disease. Proteinuria in F1 recipients injected with BALB/c or $\mathrm{A} / \mathrm{J}$ anti- $\alpha 3$ (IV) antibodies was much higher than in controls: $7.45 \pm 2.23$ (BALB/c nephritic sera) vs. $6.67 \pm 2.53$ (A/J nephritic sera) vs. $0.84 \pm 0.31 \mathrm{mg} / 16 \mathrm{~h}$ (CFA control sera). Histology revealed hypercellularity in the glomeruli with occasional crescents ( $20 \%$ of the glomeruli at $3 \mathrm{wk})$ and early tubulointerstitial infiltrates in F1 mice receiving either $\mathrm{BALB} / \mathrm{c}$ or $\mathrm{A} / \mathrm{J}$ sera (data not shown). The kidneys from control mice were histologically normal.

Adoptive transfer studies in disease-susceptible SJL mice. Donor SJL mice were immunized with $\alpha 3$ (IV) NC1 collagen. $18 \mathrm{~d}$ later, spleen and lymph node cells were harvested for transfer (32). $10^{7}$ immune cells were administered intravenously to low-dose cyclophosphamide-pretreated syngeneic recipients. Low-dose cyclophosphamide pretreatment was used because initial cell transfers without pretreatment did not produce disease (data not shown); cyclophosphamide is known to improve adaptation of transferred cells by reducing native regulatory $\mathrm{T}$ cell populations in naive recipient mice (41). Recipient mice were monitored for elevation in urine protein and serum creatinine levels. Control mice were injected with cells from adjuvant control mice. These cohorts were then killed after 4 mo. The kidneys and lungs were evaluated for immune cell infiltrates and pathology associated with disease. Kidneys from the experimental animals revealed moderate crescentic glomerulonephritis, with tubulointerstitial disease and linear staining for mouse IgG on the GBM and tubular basement membrane (Fig. 5, $E$ and $F$ ). The lung histopathology was normal (data not shown). Control mice did not exhibit abnormal pathology in the kidney and lungs (Fig. $5 \mathrm{D}$ ). The lungs from the experimental group revealed insignificant changes compared with control mice within the time frame of the experiment (data not shown). These results suggest that immune cells also transfer nephritis adoptively. As in the passive transfer experiments above, whether a longer period of observation would have produced more damage to the lungs, or what the special role of adjuvant in accelerating inflammation might be, were not determined in this set of experiments.

We next performed two additional experiments to assess further the role of $\mathrm{T}$ cells in the expression of anti-GBM disease. In the first experiment, $\mathrm{TcR}-/-$ mice (28) were immunized with $\alpha 3(\mathrm{IV}) \mathrm{NC1}$ collagen and, when compared with
TcR $+/+$ controls, did not produce anti-GBM antibodies (data not shown) or disease (Fig. 6, $A$ and $C$ ); these TcR $-/-$ mice also did not develop proteinuria $(0.54 \pm 0.12 \mathrm{mg} / 16 \mathrm{~h})$ when compared with wild-type mice $(5.43 \pm 1.22 \mathrm{mg} / 16 \mathrm{~h})$. In a second experiment, anti- $\alpha 3$ (IV) NC1 antibodies generated in disease-susceptible C57BL/6 mice were passively transferred into naive syngeneic $\mathrm{TcR}+/+$ or $\mathrm{TcR}-/-$ recipients. After $3 \mathrm{wk}$, kidneys from TcR $-/-$ recipients contained anti-GBM antibody but did not develop disease when compared with $\mathrm{TcR}+/+$ mice (Fig. 6, $B$ and $D$ ); these TcR $-/-$ mice also did not develop proteinuria $(0.44 \pm 0.11 \mathrm{mg} / 16 \mathrm{~h})$ when compared with wild-type mice $(3.78 \pm 1.01 \mathrm{mg} / 16 \mathrm{~h})$.

Assessment of the nephritogenic T cell phenotype. In the first experiment, antibodies reactive to $\alpha 3$ (IV) NC1 domains were IgG-isotyped in a panel of SJL, A/J, A.SW, and $(\mathrm{A} / \mathrm{J} \times \mathrm{SJL})$ F1 mice immunized to produce disease. All mice demonstrated significant levels of the $\mathrm{IgG} 1 / \mathrm{Th} 2$-like isotype, whereas only SJL and A.SW nephritic mice showed significant titers for IgG2a/Th1-like isotype (Fig. 7). The same pattern of isotype IgG was observed in antibodies eluted from the kidneys of SJL and A/J mice (data not shown). Anti- $\alpha 3$ (IV) NC1 IgG2b and IgG3 antibodies were not detectable in any of the immunized strains.

Kidney tissue from susceptible SJL and nonsusceptible A/J mice were further stained by immunohistochemistry for the presence of IL-12 and IL-4. Cortical kidney tissue from SJL mice with $12 \mathrm{wk}$ of disease stained for IL-12 principally in glomerular crescents (Fig. $8 A$ ), but not the tufts themselves, and in tubular casts (Fig. $8 \mathrm{~B}$ ). Rare tubular cells stained for IL-12 (not shown); presumably, the IL-12 in the casts derived from release into Bowman's space. A/J kidneys did not stain for IL-12 (Fig. $8 \mathrm{C}$ ), and neither stained positive for IL-4 (Fig.

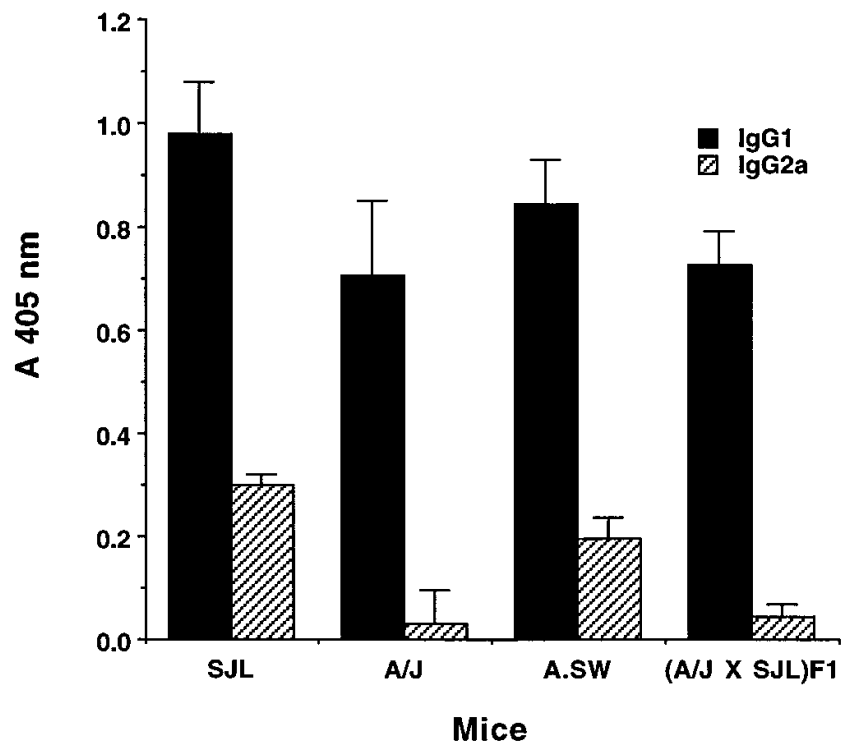

Figure 7. Isotyping of anti- $\alpha 3$ (IV) NC1-specific IgG repertoire. Direct ELISA was performed to analyze the $\alpha 3$ (IV) NC1-reactive IgG repertoire in SJL, A/J, A.SW, and $(\mathrm{A} / \mathrm{J} \times \mathrm{SJL}) \mathrm{F} 1$ mice. Isotype-specific anti-mouse IgG antibodies were used to develop this analysis (Sigma Chemical Co.). Denatured mouse $\alpha 3$ (IV) NC1 hexamer (100 ng) was used as the antigen. The primary antibody dilutions for each of the mice were 1:200. 

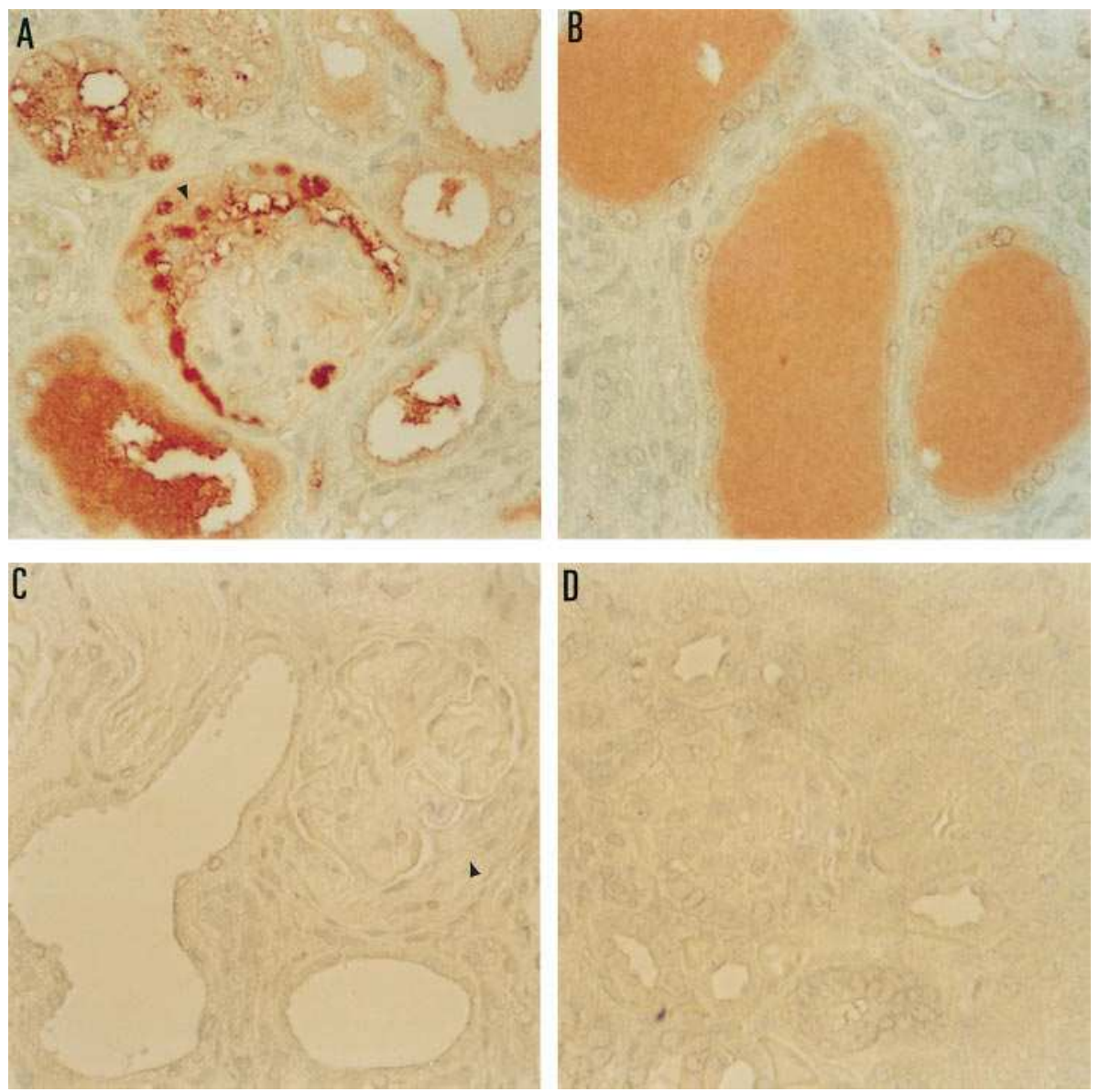

Figure 8. Kidney tissue staining for IL-12 and IL-4. Kidney sections from various haplotypes were immunostained for IL-12 and IL-4 12 wk after immunization to produce anti-GBM disease. $(A) \mathrm{SJL}$ kidney stained for IL-12, showing peroxidase reaction product in the glomerular crescent. (B) SJL kidney stained for IL-12, showing reaction product in tubular casts. (C) SJL kidney stained for IL-4, showing no reaction product in the renal cortex (arrow in crescent). (D) A/J kidney stained for IL-12, showing no reaction product in the renal cortex. In each panel, there was a primary staining with goat antibody to IL-12 and IL-4 followed by a second incubation with horseradish peroxidaselabeled rabbit anti-goat IgG; $\times 250$.
$8 D$ shows SJL). We also stained for IL-10 and IFN- $\gamma$, and the findings were identical to those observed for IL-4 and IL-12, respectively (data not shown). These results along with the antibody isotyping suggest a connection between the presence of a Th1-like response (42) and susceptibility to anti-GBM nephritis.

Oral tolerance studies in susceptible mice. SJL mice were fed one of two doses ( 65 or $700 \mu \mathrm{g}$ ) of either type IV collagen containing $\alpha 3(\mathrm{IV}) \mathrm{NC} 1$ dimers or BSA before immunization with the antigen, to determine if oral feeding could attenuate tissue inflammation. Two different doses were used because of reports that low and high doses of tolerogen induced tolerance by different mechanisms $(43,44) .2$ mo later, they were evaluated for urine protein and serum creatinine. The BSA-fed or unfed mice immunized with antigen revealed increases in urine protein and serum creatinine levels (Fig. 9). Histological examination of kidneys from these mice demonstrated crescentic glomerulonephritis with interstitial infiltrates. However, mice immunized with antigen after being prefed $\mathrm{NC1}$ domains (both 700- and 65- $\mu \mathrm{g}$ doses) showed a substantial decrease in numbers of crescents, and complete amelioration of the interstitial disease (Fig. 9); the effect in mice fed with NC1 domains at high doses was similar in those fed low doses. Our results are consistent with those observed in other antigen systems (35, $36,43,45-47)$. IgG-isotyping experiments using $\alpha 3$ (IV) NC1 domains as the target antigen revealed a decrease in the titers of IgG2a antibodies in mice prefed $\alpha 3$ (IV) $\mathrm{NC} 1$ domains in the type IV collagen diet compared with BSA-fed and unfed mice. All groups had robust levels of anti- $\alpha 3$ (IV) IgG1 antibodies
(Fig. 9). IL-12 expression was observed in all the unfed and BSA-fed mice immunized to produce disease (Fig. 10); mice prefed NC1 domains had notably less IL-12 expression in the kidney. These results suggest that oral tolerance to the $\alpha 3$ (IV)

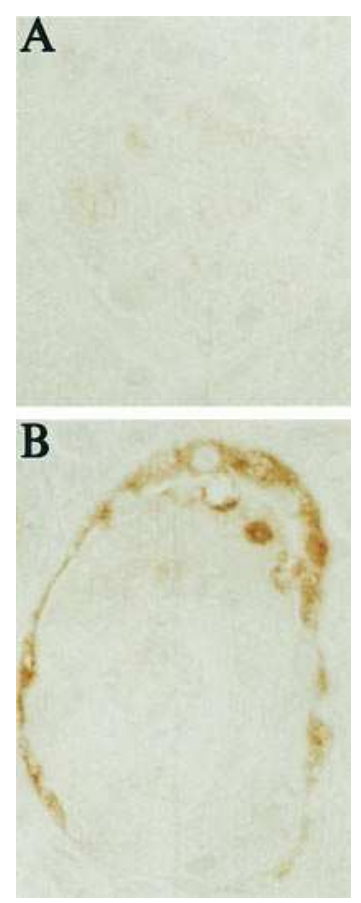

Figure 10. IL-12 staining of kidney tissue from oral tolerance experiments. Kidney sections from BSA-fed and $\mathrm{NC1}$ domain-fed SJL mice were immunostained for IL-12 $10 \mathrm{wk}$ after immunization to produce anti-GBM disease. ( $A$ ) NC1 domain-fed SJL kidney stained for IL-12, showing significantly decreased reaction product in the glomeruli. In each panel, there was a primary staining with goat antibody to IL-12 followed by a second incubation with horseradish peroxidase-labeled rabbit anti-goat IgG; $\times 250$. (B) BSA-fed SJL kidney stained for IL-12, showing peroxidase reaction product in the glomerular crescent. 


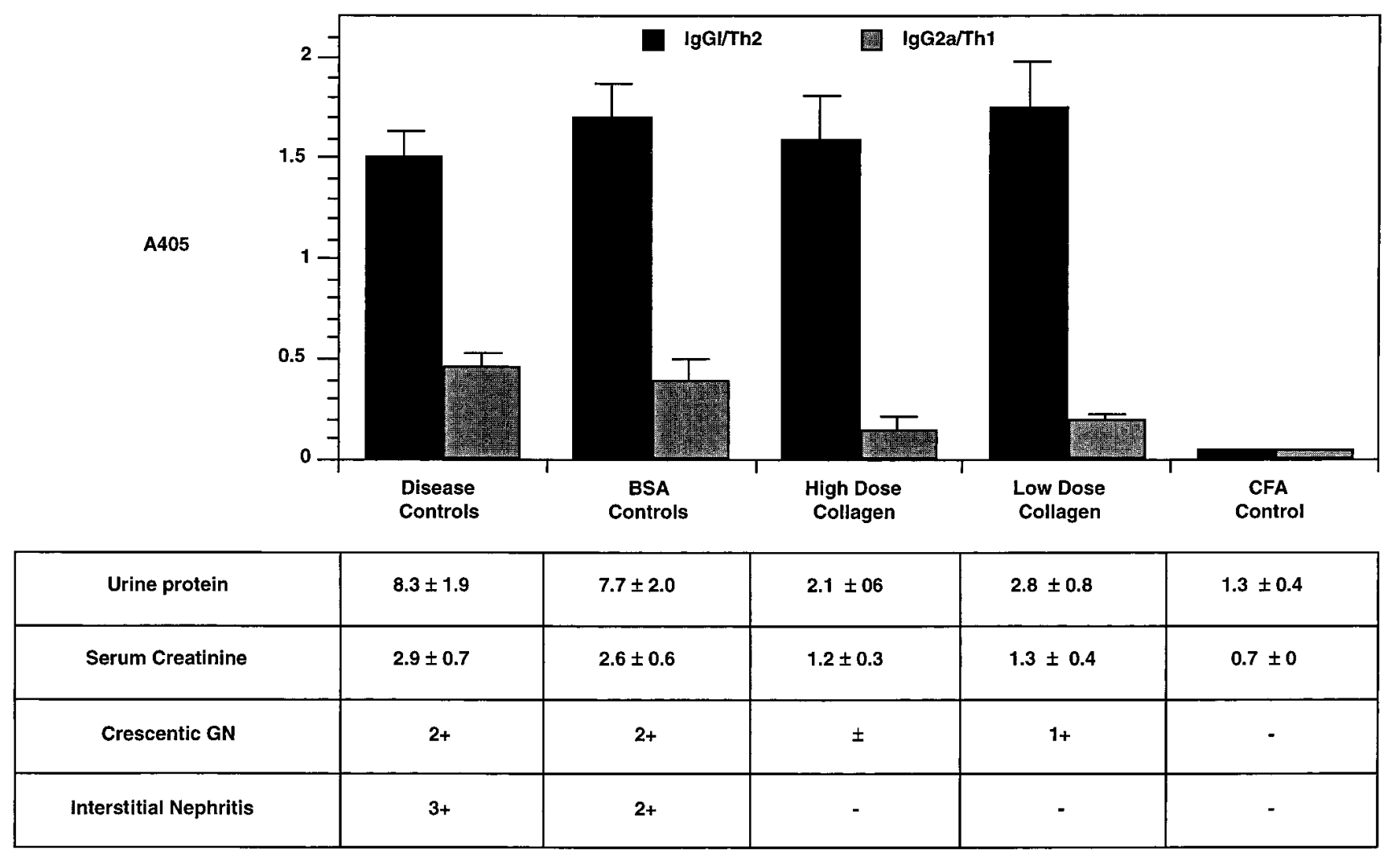

Figure 9. Isotyping of anti- $\alpha 3(\mathrm{IV}) \mathrm{NC1}$-specific IgG repertoire in SJL mice fed with BSA and $\alpha 3(\mathrm{IV})$ NC1-containing dimers. Direct ELISA was performed to analyze the $\alpha 3$ (IV) NC1-reactive IgG repertoire in several groups of SJL mice. Disease control mice were immunized with $\alpha 3$ (IV) NC1 alone, BSA control mice were immunized with $\alpha 3$ (IV) NC1 domains and fed BSA (high and low doses pooled because the results were similar), high or low dose collagen mice were immunized with $\alpha 3$ (IV) NC1 domains and fed either $700 \mu \mathrm{g} / \mathrm{high}$ dose or $65 \mu \mathrm{g} / \mathrm{low}$ dose $\alpha 3$ (IV) NC1-containing dimers, and CFA control mice were immunized with CFA adjuvant alone. Isotype-specific anti-mouse IgG antibodies were used to develop this analysis (Sigma Chemical Co.). Denatured mouse $\alpha 3(\mathrm{IV})$ NC1 hexamer (100 ng) was used as the antigen. The primary antibody dilutions for each of the mice were 1:200. Crescentic glomerulonephritis, interstitial nephritis, urine protein, and serum creatinine were determined as described for Tables I and II.

$\mathrm{NC1}$ antigen in murine anti-GBM disease attenuates IL-12/ Th1-like T cell responses.

\section{Discussion}

Immunization of disease-susceptible mice with $\alpha 3(\mathrm{IV}) \mathrm{NC} 1$ collagen produces lung hemorrhage, crescentic glomerulonephritis, interstitial renal disease, and progressive renal failure. Tissue-eluted antibodies bind specifically to $\alpha 3$ (IV) NC1 collagen, and these antibody repertoires overlap in specificity with human Goodpasture antibodies. Nephritic antibodies from SJL mice bind to the human and mouse GBM in a linear fashion, suggesting corecognition of antigens in similar distribution. Human Goodpasture antibody also blocks significantly the binding of nephritic mouse anti- $\alpha 3$ (IV) antibody to mouse hexamer. This was observed best with mouse antibodies eluted from kidney and lung, but not at all with circulating antibody.

This seemingly curious finding with circulating antibody is likely explained by the differences in how these sets of antibodies were generated. Human Goodpasture antibodies arise spontaneously and are directed to cryptic epitopes buried in associated hexamer that escape tolerance (10). Circulating antibodies from immunized mice recognize the same cryptic $\alpha 3(\mathrm{IV}) \mathrm{NC1}$ epitopes as the human antibodies and antibodies eluted from mouse lung and kidney, but also contain species that recognize other disease-irrelevant $\alpha 3$ (IV) epitopes probably created by exposure of the immunogen to biochemical purification and the process of adjuvant immunization. These latter antibodies would not be expected to inhibit human Goodpasture antisera. In spite of this understandable quirk, there appears to be appropriate commonality in the recognition specificity of tissue-bound antibodies between humans and mice with disease.

Most recent investigations suggest that the principal specificity of human anti-GBM antibodies is towards $\alpha 3$ (IV) $\mathrm{NC1}$ domain of type IV collagen (26). Antibodies from nephritic mice in these experiments share this human specificity and, therefore, are capable of transferring disease to syngeneic naive recipients. Earlier passive transfer experiments performed in sheep and primates $(14,48)$ also demonstrated the capacity of heterologous antibodies to crude GBM to transfer nephritis. Whether this nephritis is the same as that in humans or in our mouse model is unclear. The target antigens for those heterologous anti-GBM antibodies are not known. Additionally, inflammatory mediators stimulated by the antiallotype effect of passively transferring heterologous antibodies were not taken into consideration when assigning pathogenicity to primary antibodies expressed in an autologous environment. 
We also identified several genetic factors pertaining to the location, initiation, and intensity of anti-GBM disease. Human patients with anti-GBM disease and GPS are phenotypically diverse. Some have disease limited to the kidney $(4,26)$, like DBA/2 mice, some have aggressive disease in both organs (4, 26), like SJL and to a lesser extent BALB/c, B6, and B10 mice, and some have antibodies without much inflammation (22, 49), like A/J, AKR, and CBA mice. Some patients have disease limited to the lung; however, no mice to date express this phenotype.

The class II MHC locus is a polymorphic region for immune response genes, and seems to be an important modulator of the immune response to $\alpha 3$ (IV) NC1 domains. Human alleles mapping to HLA-DR (E $\beta / E \alpha$ in mice) and -DQ $(\mathrm{A} \beta / \mathrm{A} \alpha$ in mice) are associated with the inflammatory response of GPS in humans $(8,9)$. Limited sample size and the linkage disequilibrium between certain DR and DQ alleles in human antiGBM nephritis have made it difficult to attribute susceptibility to one region more than the other (9). In this study, we were able to link susceptibility to anti-GBM disease in mice to the $A \beta / A \alpha$ region in $H-2^{\text {s; }}$ this suggests that the HLA-DQ region should be studied more closely in humans with anti-GBM nephritis. Of course, non-MHC genes also map in or near the genomic location of class II. However, the non-MHC loci in this region are usually considered unlikely candidates for susceptibility genes because they do not express enough polymorphisms to explain multiple strain variations.

Curiously, the accessibility of $\alpha 3$ (IV) collagen to anti-GBM antibodies in lung basement membrane also maps to MHC class II. Western blots of lung tissue in vitro from $\mathrm{A} / \mathrm{J}, \mathrm{SJL}$, A.SW, and $(\mathrm{A} / \mathrm{J} \times \mathrm{SJL}) \mathrm{F} 1$ mice indicate that similar amounts of $\alpha 3$ (IV) collagen are present in all lung tissues in spite of the failure of lung from $\mathrm{A} / \mathrm{J}$ and $(\mathrm{A} / \mathrm{J} \times \mathrm{SJL}) \mathrm{F} 1$ crosses to bind antibody in vivo. These findings suggest that epitope accessibility in the lung is polymorphic. How prevalent such polymorphisms are in humans, and whether this MHC gene effect is a modification of structure or bears subtly on the expression of the immune repertoire, are not yet clear.

MHC class II genes are important in the initiation of helper $\mathrm{T}$ cell activation $(50,51)$. The role of $\mathrm{T}$ cells in human antiGBM disease is only now beginning to be studied, and reports to date have simply identified $\alpha 3(\mathrm{IV}) \mathrm{NC} 1$ autoreactive $\mathrm{CD} 4^{+}$ and $\mathrm{CD}^{+} \mathrm{T}$ cells in patients with disease $(12,13)$. Earlier experiments in chickens demonstrated the ability of immune cells reactive to a mixture of antigens in solubilized GBM to transfer glomerulonephritis to naive recipients, even upon removal of the bursa (52). Anti-GBM disease in our experiments can also be transferred adoptively by lymphocytes. Additionally, TcR -/- mice do not develop anti-GBM disease after immunization with $\alpha 3$ (IV) NC1 domains compared with wildtype controls. To address further the significance of the role of $T$ cells in mediating inflammation, we transferred syngeneic anti- $\alpha 3$ (IV) antibodies passively from $\mathrm{TcR}+/+$ disease-susceptible mice into $\mathrm{TcR}-/-$ or $+/+$ recipients. After $3 \mathrm{wk}$, anti-GBM disease was observed only in $+/+$ mice. These results lend further credence to the notion that nephritogenic $\mathrm{T}$ cells in disease-susceptible mice are of pivotal importance in the expression of inflammation in anti-GBM disease. Since TcR deficiency should not affect natural killer cells or the expression of antibody-dependent cell-mediated cytotoxicity, we assume that antibody binding can further educate nephritogenic $\mathrm{T}$ cell repertoires in disease-susceptible haplotypes.
Helper $\mathrm{T}$ cells coordinate the preference for emerging effector cell or antibody repertoires probably as a net balance of Th1 and Th 2 response, respectively $(42,51,53,54)$. Production of IgG1 is part of an IL-4/Th2-like response in mice, and IgG2a is part of an IL-12/Th1-like response; these cytokines and antibody isotypes are not the only ones involved in this selection but they are reasonable markers of these dual pathways $(55,56)$. While this effect is not entirely binary $(53)$, there are some peptides that favor strongly $\mathrm{Th} 1$ and $\mathrm{Th} 2$ responses (57-59), some of which are MHC-linked (60) and based on strength of peptide/MHC interaction with TcR $(51,61)$.

Our findings using nephritogenic epitopes in the NC1 domain suggest a different balance among helper $\mathrm{T}$ cell phenotypes. We monitored these $\mathrm{T}$ cell phenotypes in vivo by noting the presence of IL-12, IL-10, IL-4, or IFN- $\gamma$ in nephritic kidneys (only IL-12 and IL-4 data were shown), as well as the isotype of anti-GBM antibodies produced by various haplotypes (42). SJL, A.SW, and B10.S mice have a strong cell-mediated effector response in addition to the production of antibody, whereas $\mathrm{A} / \mathrm{J}$ mice demonstrate only an antibody response that by itself is insufficient to produce glomerulonephritis. In IgGisotyping experiments with SJL, A.SW, A/J, and (A/J $\times \mathrm{SJL})$ F1 mice, all mice had Th2-like responses, whereas only SJL and A.SW mice, strains that develop cellular infiltrates and nephritis, had additional Th1-like responses. These results support the notion that all mice respond to the $\alpha 3$ (IV) immunogen with Th2-type response, but only the haplotypes expressing appropriate MHC class II genes launch a Th1 response resulting in disease. This hypothesis is supported further by evidence of IL-12 (and IFN- $\gamma$ ) only in the glomerular lesions of diseasesusceptible mice.

Furthermore, when nephritogenic antibodies from SJL and A/J mice were passively transferred into $(\mathrm{A} / \mathrm{J} \times \mathrm{SJL}) \mathrm{F} 1$ recipients, there was no autoimmune glomerulonephritis. This critical experiment suggests that anti-GBM antibodies, regardless of isotype, are not alone sufficient to produce nephritis. However, in an allotype-compatible and disease-susceptible haplotype, antibodies from nonsusceptible mice can be nephritogenic. Such experiments, performed in (BALB/c $\times$ CA21) F1 recipients, clearly speak to the role of nonhumoral mechanisms in the expression of anti-GBM injury. We hypothesize that these nonhumoral mechanisms depend on $\mathrm{T}$ cell repertoires directed by MHC class II genes.

The absence of disease in the $(\mathrm{A} / \mathrm{J} \times \mathrm{SJL}) \mathrm{F} 1$ cross is a curiosity and special interest that has several potential explanations. There is the possibility of a simple reduction in $\mathrm{MHC}$ gene dose (62), or of the formation of new hybrid MHC molecules favoring Th2-like effector responses $(51,61)$. Furthermore, while Th1 responses prevail occasionally in some peptide/MHC interactions (60), others have suggested that IL-4/ Th2 effects dominate typically during $\mathrm{T}$ cell priming $(57,59$, 63). Part of determining this preference is probably shaped by the interaction of peptide with MHC; for example, BALB/c mice immunized with $\alpha 3$ (IV) favor a Th1 response, whereas the same mice immunized with leishmania favor a Th2-like effect $(64,65)$.

The dominant-negative effects of the $(\mathrm{A} / \mathrm{J} \times \mathrm{SJL}) \mathrm{F} 1$ cross might also be explained by a change in the relative balance or opposing action of anti- $\alpha 3$ (IV) NC1 clones (53). In this vein, selected strains like SJL would have strong, bidirectional Th1and Th2-like responses, B6, BALB/c, and B10 mice a weaker Th1- and similar Th2-like responses, and A/J and AKR mice a 
Th2-like response alone. The dominant-negative cross, therefore, could be viewed as favoring heavily a Th2-like effect. Such bias may be self-protective in this autoimmune disease, and fundamental in explaining the low incidence of GPS in humans, where nonfamilial breeding is socially preferred. Further verification of a bidirectional balance in this hypothesis will require special examination of $\alpha 3$ (IV) NC1-reactive T cell repertoires.

Finally, we were able to downregulate the nephritogenic cell-mediated response in SJL mice by tolerizing them with oral feeding of $\alpha 3$ (IV) NC1 target antigen. This modulation of disease has been observed in other systems $(35,43,44,47,66)$. The primary mechanism by which orally administered antigen induces tolerance is thought to be the attenuation of $\mathrm{T}$ cell clones; low doses of orally administered antigen favor active suppression, whereas higher doses favor clonal anergy $(43,47)$. Our results suggest a preferential effect on the Th1 repertoire responsible for the nephritis, perhaps by reducing the expression of tissue IL-12 or other cytokines in that cascade. Recent findings in other models argue that antigen feeding generates Th2-like responses in gut-associated lymphoid tissue and the emergence of cytokines such as TGF- $\beta$ and IL- 4 , which tend to suppress proinflammatory Th1-like responses $(35,43,44,47)$.

\section{Acknowledgments}

We wish to thank Michelle C. Werner and Mark Schwartz for their assistance in maintaining mice colonies and collection of tissues and blood from mice.

This work was supported in part by grants DK-46282, DK-07006, DK-30280, DK-02334, and DK-45191 from the National Institutes of Health, the DCI RED fund, and grant B170196 from BioStratum Inc.; Dr. Kalluri is a founder and consultant in Biostratum Inc. and owns equity in the company. Dr. Okada was a recipient of a fellowship from Eli Lilly Japan, Ltd.

\section{References}

1. Morrison, K.E., M. Mariyama, T.L. Yang-Feng, and S.T. Reeders. 1991. Sequence and localization of a partial cDNA encoding the human $\alpha 3$ chain of type IV collagen. Am. J. Hum. Genet. 49:545-554.

2. Kalluri, R., F.A. Shield, P. Todd, B.G. Hudson, and E.G. Neilson. 1997. Isoform switching of type IV collagen is developmentally arrested in X-linked Alport syndrome increasing susceptibility to endoproteolysis. J. Clin. Invest. 99: 2470-2478.

3. Hudson, B.G., S.T. Reeders, and K. Tryggvason. 1993. Type IV collagen: structure, gene organization, and role in human diseases. Molecular basis of Goodpasture and Alport syndromes and diffuse leiomyomatosis. J. Biol. Chem. 268:26033-26036.

4. Meyers, C.M., R. Kalluri, and E.G. Neilson. 1997. Anti-basement membrane antibodies in Goodpasture syndrome. In Immunologic Renal Diseases. E.G. Neilson and W.C. Couser, editors. Lippincott-Raven Publishers, New York. 959-975.

5. Kalluri, R., L.P. van den Heuvel, H.J. Smeets, C.H. Schroder, H.H. Lemmink, A. Boutaud, E.G. Neilson, and B.G. Hudson. 1995. A COL4A3 gene mutation and post-transplant anti-alpha 3(IV) collagen alloantibodies in Alport syndrome. Kidney Int. 47(4):1199-1204.

6. D'Apice, A.J.F., P. Kincaid-Smith, G.J. Becker, M.G. Loughhead, J.W. Freeman, and J.M. Sands. 1978. Goodpasture's syndrome in identical twins. Ann. Intern. Med. 88:61-62.

7. Gossain, V.V., A.R. Gerstein, and A.W. Janes. 1972. Goodpasture's syndrome: a familial occurrence. Am. Rev. Respir. Dis. 105:621-624.

8. Rees, A.J., D.K. Peters, N. Amos, K.I. Welch, and J.R. Batchelor. 1984. The influence of HLA-linked genes on the severity of anti-GBM antibody-mediated nephritis. Kidney Int. 26:444-450.

9. Huey, B., K. McCormick, J. Crapper, C. Ratliff, B.W. Colombe, M.R. Garovoy, and C.B. Wilson. 1993. Associations of HLA-DSR and HLA-DQ types with anti-GBM nephritis by sequence-specific oligonucleotides probe hybridization. Kidney Int. 44:307-312.

10. Kalluri, R., M.J. Sun, B.G. Hudson, and E.G. Neilson. 1996. The Good- pasture autoantigen: structural delineation of two immunologically privileged epitopes on $\alpha 3(\mathrm{IV})$ chain of type IV collagen. J. Biol. Chem. 271:9062-9068.

11. Kalluri, R., S. Gunwar, S.T. Reeders, K.C. Morrision, M. Mariyama, K.E. Ebner, M.E. Noelken, and B.G. Hudson. 1991. Goodpasture syndrome: localization of the epitope for the autoantibodies to the carboxyl-terminal region of the $\alpha 3(\mathrm{IV})$ chain of basement membrane collagen. J. Biol. Chem. 266: 24018-24024.

12. Merkel, F., R. Kalluri, M. Marx, U. Enders, E.G. Neilson, H.G. Rammensee, B.G. Hudson, and M. Weber. 1995. Autoreactive T-cells in Goodpasture syndrome recognize the N-terminal NC1 domain of the $\alpha 3$ chain of type IV collagen. Kidney Int. 49:1127-1129.

13. Derry, C.J., C.N. Ross, G. Lombardi, P.D. Mason, A.J. Rees, R.I Lechler, and C.D. Pusey. 1995. Analysis of T cell responses to the autoantigen in Goodpasture's disease. Clin. Exp. Immunol. 100:262-268.

14. Lerner, R.A., and F.J. Dixon. 1966. Transfer of ovine experimental allergic glomerulonephritis (EAG) with serum. J. Exp. Med. 124:431-442.

15. Salant, D.J., and A.V. Cybulsky. 1988. Experimental glomerulonephritis. Methods Enzymol. 162:421-461.

16. Wilson, C.B. 1997. Animal models for glomerulonephritis. In Immunologic Renal Diseases. E.G. Neilson and W.C. Couser, editors. Lippincott-Raven Publishers, New York. 729-804.

17. Couser, W.G., C. Darby, D.J. Salant, S. Adler, M.M. Stilmant, and L.M. Lowenstein. 1985. Anti-GBM antibody-induced proteinuria in isolated perfused rat kidney. Am. J. Physiol. 249:F241-F250.

18. Madaio, M.P., D.J. Salant, S. Adler, C. Darby, and W.G. Couser. 1984. Effect of antibody charge and concentration on deposition of antibody to glomerular basement membrane. Kidney Int. 26:397-403.

19. Hill, P.A., H.Y. Lan, D.J. Nikolic-Paterson, and R.C. Atkins. 1994. The ICAM-1/LFA-1 interaction in glomerular leukocytic accumulation in antiGBM glomerulonephritis. Kidney Int. 45:700-708.

20. Nishikawa, K., Y.J. Guo, M. Miyasaka, T. Tamatani, A.B. Collins, M.S. Sy, R.T. McCluskey, and G. Andres. 1993. Antibodies to intercellular adhesion molecule $1 /$ lymphocyte function-associated antigen 1 prevent crescent formation in rat autoimmune glomerulonephritis. J. Exp. Med. 177:667-677.

21. Nishikawa, K., P.S. Linsley, A.B. Collins, I. Stamenkovic, R.T. McCluskey, and G. Andres. 1994. Effect of CTLA-4 chimeric protein on rat autoimmune anti-glomerular basement membrane glomerulonephritis. Eur. J. Immunol. 24:1249-1254.

22. Wilson, C.B. 1996. Renal response to immunological glomerular injury. In The Kidney, Volume II. B. Brenner, editor. W.B. Saunders Company, Philadelphia. 1253-1391.

23. Avasthi, P.S., P. Avasthi, S. Tokuda, R.E. Anderson, and R.C. Williams. 1971. Experimental glomerulonephritis in the mouse. Clin. Exp. Immunol. 9: 667-676.

24. Bolton, W.K., F.R. Benton, and B.C. Sturgill. 1978. Autoimmune glomerulotubular nephropathy in mice. Clin. Exp. Immunol. 33:463-473.

25. Wick, G., H. von der Mark, H. Dietrich, and R. Timpl. 1986. Globular domain of basement membrane collagen induces autoimmune pulmonary lesions in mice resembling human Goodpasture disease. Lab. Invest. 55:308-317.

26. Kalluri, R., C.B. Wilson, M. Weber, S. Gunwar, A.M. Chonko, E.G. Neilson, and B.G. Hudson. 1995. Identification of the $\alpha 3($ IV) chain of type IV collagen as the common autoantigen in anti-basement membrane disease and Goodpasture syndrome. J. Am. Soc. Nephrol. 6:1178-1185.

27. Kalluri, R., V.H. Gattone, Jr., M.E. Noelken, and B.G. Hudson. 1994 The $\alpha 3$ (IV) chain of type IV collagen induces autoimmune Goodpasture syndrome. Proc. Natl. Acad. Sci. USA. 91:6201-6205.

28. Mombaerts, P., E. Mizoguchi, M.J. Grunsby, L.H. Glimcher, A.K. Bhan, and S. Tonegawa. 1993. Spontaneous development of inflammatory bowel disease in T cell receptor mutant mice. Cell. 75:275-282.

29. Neilson, E.G., and S.M. Phillips. 1982. Murine interstitial nephritis. I. Analysis of disease susceptibility and its relationship of pleiomorphic gene products defining both immune-response genes and a restrictive requirement for cytotoxic T cells at H-2K. J. Exp. Med. 155:1075-1085.

30. Kahsai, T., G. Enders, S. Gunwar, R. Kalluri, J. Zhou, and B. Hudson. 1997. Seminiferous tubule basement membrane: composition of type IV collagen chains, and abundance of the $\alpha 3$ (IV) chain, the Goodpasture antigen and alport alloantigen. J. Biol. Chem. 272:17023-17032.

31. Gunwar, S., F. Ballester, R. Kalluri, J. Timoneda, A.M. Chonko, S.J. Edwards, M.E. Noelken, and B.G. Hudson. 1991. Glomerular basement membrane: identification of dimeric subunits of the noncollagenous domain (hexamer) of collagen IV and the Goodpasture antigen. J. Biol. Chem. 266:1531815324.

32. Zakheim, B., E. McCafferty, S.M. Phillips, M. Clayman, and E.G. Neilson. 1984. Murine interstitial nephritis. II. The adoptive transfer of disease with immune T lymphocytes produces a phenotypically complex interstitial lesion. $J$. Immunol. 133:234-239.

33. Strutz, F. H. Okada, C.W. Lo, T. Danoff, R.L Carone, J.E. Tomaszewski, and E.G. Neilson. 1995. Identification and characterization of a fibroblast marker: FSP1. J. Cell Biol. 130:393-405.

34. Kalluri, R., E. Melendez, W.K. Rumpf, K. Sattler, G.A. Muller, F. Strutz, and E.G. Neilson. 1996. Specificity of circulating and tissue-bound autoantibodies in Goodpasture syndrome. Proc. Assoc. Am. Physicians. 108:134-139. 
35. Chen, Y., and H. Weiner. 1996. Dose-dependent activation and deletion of antigen-specific T cells following oral tolerance. Ann. NY Acad. Sci. 778:111-121.

36. Chen, Y., V.K. Kuchroo, J. Inobe, D.A. Hafler, and H.L. Weiner. 1994. Regulatory T cell clones induced by oral tolerance: suppression of autoimmune encephalomyelitis. Science (Wash. DC). 265:1237-1240.

37. Jones, P.P., D.B. Murphy, and H.O. McDevitt. 1981. Variable synthesis and expression of $\mathrm{E} \alpha$ and $\mathrm{Ae}(\mathrm{E} \beta)$. Ia polypeptide chains in mice of different H-2 haplotypes. Immunogenetics. 12:321-329.

38. Neilson, E.G., R. Kalluri, M.J. Sun, S. Gunwar, T. Danoff, M. Mariyama, J.C. Myers, S.T. Reeders, and B.G. Hudson. 1993. Specificity of Goodpasture autoantibodies for the recombinant noncollagenous domains of human type IV collagen. J. Biol. Chem. 268:8402-8405.

39. Riblet, R., and P.H. Brodeur. 1986. The Igh-V gene repertoire of the mouse. Mt. Sinai J. Med. 53:170-174.

40. Riblet, R., A. Tutter, and P. Brodeur. 1986. Polymorphism and evolution of Igh-V gene families. Curr. Top. Microbiol. Immunol. 127:168-172.

41. Kelly, C.J., R. Korngold, R. Mann, M. Clayman, T. Haverty, and E.G. Neilson. 1986. Spontaneous interstitial nephritis in kdkd mice. II. Characterization of a tubular antigen-specific, H-2K-restricted Lyt-2 ${ }^{+}$effector T cell that mediates destructive tubulointerstitial injury. J. Immunol. 136:526-531.

42. Seder, R.A., and W.E. Paul. 1994. Acquisition of lymphokine-producing phenotype by CD4+ T cells. Annu. Rev. Immunol. 12:635-674.

43. Weiner, H.L., A. Friedman, A. Miller, S.J. Khoury, A. Al-Sabbagh, L. Santos, M. Sayegh, R.B. Nussenblatt, D.E. Trentham, and D.A. Hafler. 1994. Oral tolerance: immunologic mechanisms and treatment of animal and human organ-specific autoimmune diseases by oral administration of autoantigens. Annu. Rev. Immunol. 12:809-837.

44. Sosroseno, W. 1995. A review of the mechanisms of oral tolerance and immunotherapy. J. R. Soc. Med. 88:14-17.

45. Chen, Y., J. Inobe, and H.L. Weiner. 1995. Induction of oral tolerance to myelin basic protein in CD8-depleted mice: both CD4+ and CD8+ cells mediate active suppression. J. Immunol. 155:910-916.

46. Akselband, Y., T.L. Hoffer, P.A. Nelson, P.A. Gonnella, and H.L. Weiner. 1996. Local and systemic immune responses in SJL/J mice during prolonged oral myelin basic protein administration. Ann. NY Acad. Sci. 778:358-361.

47. Weiner, H.L. 1994. Oral tolerance. Proc. Natl. Acad. Sci. USA. 91: 10762-10765.

48. Steblay, R.W. 1962. Glomerulonephritis induced in sheep by injections of heterologous glomerular basement membrane and Freund's complete adjuvant. J. Exp. Med. 116:253-271.

49. Kalluri, R., S. Pettrides, C.B. Wilson, J.E. Tomaszewski, H.I. Palevsky, M.A. Grippi, M. Madaio, and E.G. Neilson. 1996. Anti- $\alpha 1($ IV) collagen autoantibodies associated with lung adenocarcinoma presenting as the Goodpasture syndrome. Ann. Intern. Med. 124:651-653.

50. Germain, R.N. 1994. MHC-dependent antigen processing and peptide presentation: providing ligands for T-lymphocyte activation. Cell. 76:287-300.

51. Janeway, C.A., Jr., and K. Bottomly. 1994. Signals and signs for lymphocyte responses. Cell. 76:275-285.
52. Bolton, W.K., F.L. Tucker, and B.C. Sturgill. 1984. New avian model of experimental glomerulonephritis consistent with mediation by cellular immunity. Nonhumorally mediated glomerulonephritis in chickens. J. Clin. Invest. 73: 1263-1276.

53. Kelso, A. 1995. Th1 and Th2 subsets: paradigm lost? Immunol. Today. 16:374-379.

54. Romagnani, S. 1995. Biology of human TH1 and TH2 cells. J. Clin. Immunol. 15:121-129.

55. Finkelman, F.D. J. Holmes, I. Katona, J.F. Urban, M.P. Beckman, L.S. Park, K.A. Schooley, R.L. Coffman, T.R. Mosmann, and W.E. Paul. 1990. Lymphokine control of in vivo immunoglobulin isotype selection. Annu. Rev. Immunol. 8:303-334.

56. Constant, S.L., and K. Bottomly. 1997. Induction of the ThI and Th2 CD4+ T cell responses: the alternative approaches. Annu. Rev. Immunol. 15 297-322.

57. Hsieh, C., S. Macatonia, C.S. Tripp, S.F. Wolf, and A. O'Garra. 1993. Development of Th1 CD4 ${ }^{+} \mathrm{T}$ cells through IL-12 produced by listeria-induced macrophages. Science (Wash. DC). 260:547-550.

58. Pfeiffer, C., J. Murray, J. Madri, and K. Bottomly. 1991. Selective activation of Th1- and Th2-like cells in vivo-response to human collagen IV. Immunol. Rev. 123:65-84.

59. Perez, V.L., J.A. Lederer, A.H. Lichtman, and A.K. Abbas. 1995. Stability of Th1 and Th2 populations. Int. Immunol. 7:869-875.

60. Murray, J.S., J. Madri, J. Tite, S.R. Carding, and K. Bottomly. 1989. MHC control of CD4 ${ }^{+}$T cell subset activation. J. Exp. Med. 170:2135-2140.

61. Pfeiffer, C., J. Stein, S. Southwood, H. Ketelaar, A. Sette, and K. Bottomly. 1995. Altered peptide ligands can control CD4 T lymphocyte differentiation in vivo. J. Exp. Med. 181:1569-1574.

62. Schwartz, R.H., C.F. Merryman, and P.H. Maurer. 1979. Gene complementation in the T lymphocyte proliferative response to poly $\left(\mathrm{Glu}^{57} \mathrm{Lys}^{38} \mathrm{Tyr}^{5}\right)$ evidence for effects of polymer handling and gene dosage. J. Immunol. 123: 272-277.

63. Seder, R.A., R. Gazzinelli, A. Sher, and W.E. Paul. 1993. IL-12 acts directly on $\mathrm{CD}^{+} \mathrm{T}$ cells to enhance priming for IFN $\gamma$ production and diminishes IL-4 inhibition of such priming. Proc. Natl. Acad. Sci. USA. 90:10188-10193.

64. Guler, M.L., J.D. Gorham, C.S. Hsieh, A.J. Mackey, R.G. Steen, W.F. Dietrich, and K.M. Murphy. 1996. Genetic susceptibility to Leishmania: IL-12 responsiveness in TH1 cell development. Science (Wash. DC). 271:984-987.

65. Noben-Trauth, N., P. Kropf, and I. Muller. 1996. Susceptibility to Leishmania major infection in interleukin-4-deficient mice. Science (Wash. DC). 271: 987-990.

66. Sayegh, M.H., S.J. Khoury, W.W. Hancock, H.L. Weiner, and C.B. Carpenter. 1996. Mechanisms of oral tolerance by MHC peptides. Ann. NY Acad. Sci. 778:338-345.

67. Gunwar, S., J. Saus., M.E. Noelken, and B.G. Hudson. 1990. Glomerular basement membrane. Identification of a fourth chain, $\alpha 4$, of type IV collagen. J. Biol. Chem. 265:5466-5469. 